\title{
Distributions of three Alexandrium species and their toxins across a salinity gradient suggest an increasing impact of GDA producing $A$. pseudogonyaulax in shallow brackish waters of Northern Europe
}

\author{
Anke Kremp $^{\mathrm{a}, \mathrm{b}, *}$, Per Juel Hansen ${ }^{\mathrm{c}}$, Urban Tillmann ${ }^{\mathrm{d}}$, Henna Savela ${ }^{\mathrm{b}, \mathrm{e}}$, Sanna Suikkanen ${ }^{\mathrm{b}}$, \\ Daniela Voß $^{\mathrm{f}}$, Facundo Barrera ${ }^{\mathrm{g}}$, Hans Henrik Jakobsen ${ }^{\mathrm{h}}$, Bernd Krock ${ }^{\mathrm{d}}$ \\ ${ }^{a}$ Leibniz Institut für Ostseeforschung Warnemünde, Seestr. 15, 18119 Rostock, Germany \\ ${ }^{\mathrm{b}}$ Finnish Environment Institute, Marine Research Centre, Agnes Sjöbergin katu 2, 00790 Helsinki, Finland \\ ${ }^{\mathrm{c}}$ University of Copenhagen, Marine Biological Section, Strandpromenaden 5, 3000 Helsingør, Denmark \\ ${ }^{\mathrm{d}}$ Alfred-Wegener-Institut Helmholtz-Zentrum für Polar- und Meeresforschung, Am Handelshafen 12, D-27570 Bremerhaven, Germany \\ ${ }^{\mathrm{e}}$ Department of Biochemistry/Biotechnology, University of Turku, Kïnamyllynkatu 10, 20520 Turku, Finland \\ ${ }^{\mathrm{f}}$ Institut für Chemie und Biologie des Meeres (ICBM), Schleusenstr. 1, 26382 Wilhelmshaven, Germany \\ ${ }^{\mathrm{g}}$ Departamento de Química Ambiental, Facultad de Ciencias. Centro de Investigación en Biodiversidad y Ambientes Sustentables. Universidad Católica de la Santísima \\ Concepción. Alonso de Ribera 2850, 4090541, Concepción, Chile \\ ${ }^{\mathrm{h}}$ University of Århus, Institute for Bioscience, Frederiksborgvej 399, 4000 Roskilde, Denmark
}

\section{A R T I C L E I N F O}

\section{Keywords:}

Alexandrium

A. pseudogonyaulax

Northern Europe

Climate warming

Toxins

Goniodomin A

Cycloimines

Paralytic shellfish toxins

Resting cysts

Baltic Sea

\begin{abstract}
A B S T R A C T
Blooms of Alexandrium spp. are a well-known phenomenon in Northern European waters. While A. tamarense/ catenella, and A. pseudogonyaulax have been reported from marine waters, high densities of $A$. ostenfeldii are mainly observed at lower salinities in North Sea estuaries and the Baltic Sea, suggesting salinity as a driver of Alexandrium species composition and toxin distribution. To investigate this relationship, an oceanographic expedition through a natural salinity gradient was conducted in June 2016 along the coasts of Denmark. Besides hydrographic data, phytoplankton and sediment samples were collected for analyses of Alexandrium spp. cell and cyst abundances, for toxin measurement and cell isolation. Plankton data revealed the predominance of $A$. pseudogonyaulax at all transect stations while $A$. ostenfeldii and $A$. catenella generally contributed a minor fraction to the Alexandrium community. High abundances of $A$. pseudogonyaulax in the shallow enclosed Limfjord were accompanied by high amounts of goniodomin A (GDA). This toxin was also detected at low abundances along with A. pseudogonyaulax in the North Sea and the Kattegat. Genetic and morphological characterization of established strains showed high similarity of the Northern European population to distant geographic populations. Despite low cell abundances of $A$. ostenfeldii, different profiles of cycloimines were measured in the North Sea and in the Limfjord. This field survey revealed that salinity alone does not determine Alexandrium species and toxin distribution, but emphasizes the importance of habitat conditions such as proximity to seed banks, shelter, and high nutrient concentrations. The results show that $A$. pseudogonyaulax has become a prominent member of the Alexandrium spp. community over the past decade in the study area. Analyses of long term monitoring data from the Limfjord confirmed a recent shift to A. pseudogonyaulax dominance. Cyst and toxin records of the species in Kiel Bight suggest a spreading potential into the brackish Baltic Sea, which might lead to an expansion of blooms under future climate conditions.
\end{abstract}

\section{Introduction}

Species of the genus Alexandrium are prominent toxin producers and widely distributed in Northern European waters (Moestrup and Hansen, 1988; Touzet et al., 2008; Brown et al., 2010; Hakanen et al., 2012). Their various potent toxins accumulate in fish and shellfish (Anderson et al., 2012) and are therefore of major concern to the aquaculture industry in the region. Toxicities caused by blooms of Alexandrium spp. have been reported from different coasts of Northern Europe since the 1970s (Ayres, 1975, Tangen, 1983; Bresnan et al., 2008). Due to their impact on the shellfish industry, toxic Alexandrium species have been monitored extensively in marine areas. However, occurrences are

\footnotetext{
* Corresponding author at: Anke Kremp, Postal address: Leibniz Institut für Ostseeforschung Warnemünde, Seestr. 15, 18119 Rostock, Germany.

E-mail address: anke.kremp@io-warnemuende.de (A. Kremp).
} 
increasingly reported also from brackish waters of coastal inlets and the Baltic Sea (Kremp et al., 2009; van de Waal et al., 2015). The Alexandrium community in the area mainly consists of cold-water adapted $A$. tamarense sensu John et al. (2014) or A. catenella sensu Fraga et al. (2015) respectively, co-occurring with $A$. ostenfeldii, and forming blooms during spring (Moestrup and Hansen, 1988; John et al., 2003). In recent years, A. pseudogonyaulax and warm-water populations of $A$. ostenfeldii have increasingly been encountered in summer phytoplankton (Dittami et al., 2013; Hakanen et al., 2012; Wasmund et al., 2015).

Alexandrium catenella and A. tamarense represent the former A.tamarense/fundyense/catenella complex in northern European waters. A. tamarense is non-toxic (Higman et al., 2001; Collins et al., 2009), and paralytic shellfish toxicities in the North Sea area thus seem to be caused by A. catenella (Brown et al., 2010; John et al., 2014). Both, A. tamarense and A. catenella mostly occur at higher latitudes and are generally associated with lower water temperatures, compared to the other species of the complex. Nevertheless, different responses of the two co-occurring species to temperature changes may influence the distribution and relative contribution of each species in different locations (Eckford-Soper et al., 2016).

Alexandrium ostenfeldii, a major producer of neurotoxic cycloimines (Cembella et al., 2000) has been encountered together with A. tamarense/fundyense/catenella in spring phytoplankton communities of the Northern European waters (Moestrup and Hansen, 1988; Touzet et al., 2008). Bloom formation of the species was not reported in the area until a decade ago when warm water populations started to expand in the Baltic Sea (Kremp et al., 2009) and the coasts of The Netherlands (van de Waal et al., 2015). These populations have the demonstrated ability to produce both, cycloimines and paralytic shellfish toxins (PST) (van de Waal et al., 2015; Harju et al., 2016). PST production was also reported for a brackish water adapted strain from estuarine Limfjord (Hansen et al., 1992) suggesting a role of salinity for PST production in A. ostenfeldii. Experimental studies, however, have not substantiated this hypothesis so far (Suikkanen et al., 2013a).

Alexandrium pseudogonyaulax is a large dinoflagellate with a global distribution, originally described from a Mediterranean Lagoon (Biecheler, 1952). In Europe, this species is commonly reported from the Mediterranean Sea (Montresor, 1995; Bravo et al., 2006; Zmerli Triki et al., 2014), but records from northern Europe also exist (Balech, 1995; Nehring, 1997). The species prefers coastal "interior" habitats (Balech, 1995) and can be associated with brackish salinities. New occurrences and high biomasses of the species are being increasingly reported from northern temperate waters (Klein et al., 2010; Dittami et al., 2013; Wasmund et al., 2015, 2017). A. pseudogonyaulax has been shown to produce goniodomin A (GDA) (Murakami et al., 1988; Zmerli Triki et al., 2016), a macrolide polyether with toxic properties (Hsia et al., 2006). In experiments, the species affected higher trophic levels and food web transfer efficiency negatively (Blanda et al., 2016), indicating a potential effect on ecosystem function.

The recent observations of high A. ostenfeldii and A. pseudogonyaulax abundances in Northern Europe at brackish salinities and high water temperature suggest that the composition of Alexandrium species may change with climatic conditions in the area. Consequences of climate change include the freshening of coastal surface waters due to increased river run-off and higher sea surface temperatures (SST). As shown by long term monitoring data, such changes of SST affect the phytoplankton community and enhance toxic algal blooms in both, the North Sea and the Baltic Sea (Hinder et al., 2012; Suikkanen et al., 2013b). For Alexandrium, experimental data indicate that locally and seasonally adapted populations could respond sensitively to the respective changes of environmental conditions (Brown et al., 2010; Østergaard-Jensen and Moestrup, 1997). As a variety of toxins are produced by the Alexandrium community (Anderson et al., 2012) changes in Alexandrium species composition are expected to affect toxicities at the coasts of Northern Europe.
In this study, we use a natural gradient of different salinity and temperature regimes to investigate the effects of climate-sensitive and stable habitat conditions on three Alexandrium species and the composition of their respective toxins in Northern European waters. A transect survey was conducted in June 2016 along the coast of Denmark starting in marine conditions (Salinity 34) of the German Bight (Stations 1-6), crossing through shallow brackish and temperature influenced Limfjord (Stations 14-28) to the Kattegat (Stations 29-38) and Great Belt (Stations 39-41) and ending in Kiel Bight, Baltic Sea (Stations 42-44, Salinity 14). Also, time series of Alexandrium spp. monitoring data were analysed from the Limfjord, where the temperature has increased significantly over the past decade (Hansen, 2018), to substantiate climate-related changes in Alexandrium species and toxin distribution.

\section{Material and methods}

\subsection{Field sampling}

\subsubsection{Hydrographic parameters}

An oceanographic expedition was performed along the Danish coasts and the Limfjord in June 2016 on R/V Uthörn (Fig. 1) starting from Bremerhaven Germany, continuing along the Danish west coast to the entrance of the Limfjord. Several parts of the Limfjord were sampled during daily excursions from Løgstør. After that, the expedition continued from Løgstør to the Kattegat, Great Belt and Kiel Bight. A total of 44 stations were sampled (Fig. 1). At each station, CTD profiles were conducted using a Seabird 'sbe19plus V2' CTD (Sea-Bird Electronics Inc., Seattle, WA, USA $)$ attached to a sampling rosette $(6 \times 4 \mathrm{~L}$ Niskin bottles). The CTD was equipped with an additional fluorescence sensor (SCUFA Fluorometer, Turner Design, USA). Data acquisition was carried out via CTD-client onboard (Seasave V 7.22.2); post-processing was done with SBE data processing 7.22.5. Temperature was corrected to ITS-90 (Preston-Thomas 1990). CTD data are available at Pangaea database (Krock et al., 2017). Water samples were collected from specific depths during the upcast of the instrument, relating to the chlorophyll- $a$ (chl- $a$ ) fluorescence profiles during the downcast and the deep chl- $a$ maxima (DCM).

Water samples were taken simultaneously with the CTD at discrete depths, depending on the chl- $a$ maxima seen from the downcast. Chlorophyll- $a$ concentrations were determined from sampled water (500-2000 mL) filtered onto Whatman GF/F filters (nominal pore size of $0.7 \mu \mathrm{m}$ ) and analysed using a fluorometer (Arar and Collins, 1997). Chlorophyll- $a$ concentrations were used to calibrate the fluorescence values of the SCUFA fluorometer on the CTD.

\subsubsection{Plankton sampling}

At each station one or two vertical net tows were taken from the water column using a $20 \mu \mathrm{m}$ phytoplankton net (438-030, Hydro-Bios, Kiel, Germany). The depth of the hauls corresponded to the total water depth. Net tow concentrates were collected into plastic containers and diluted to a defined volume (usually $1 \mathrm{~L}$ ) with filtered seawater. $50 \mathrm{~mL}$ aliquots were then taken for cell isolations, and $18 \mathrm{~mL}$ aliquots were fixed with paraformaldehyde ( $1 \%$ final concentration) for microscopic analyses of phytoplankton. The remaining net tow volume was sizefractionated over a filter array to collect the $>200,>50$ and $>20 \mu \mathrm{m}$ fractions. Plankton of each size fraction was rinsed with filtered seawater into $50 \mathrm{~mL}$ centrifugation tubes and adjusted to $45 \mathrm{~mL}$. Of each size fraction three $15 \mathrm{~mL}$ aliquots for determination of hydrophilic (1) and lipophilic phycotoxins (2) and for DNA analysis (3) were transferred into $15 \mathrm{~mL}$ centrifuge tubes and centrifuged for $15 \mathrm{~min}$ at $3220 \mathrm{x}$ $\mathrm{g}$ and $4{ }^{\circ} \mathrm{C}$. After removal of supernatants DNA samples were frozen and stored at $-20^{\circ} \mathrm{C}$ until analysis. Cell pellets for analysis of hydrophilic and lipophilic phycotoxins were re-suspended in $1 \mathrm{~mL} 0.03 \mathrm{M}$ acetic acid or methanol, respectively, and transferred to FastPrep tubes containing $0.9 \mathrm{~g}$ lysing matrix D (Thermo-Savant, Illkirch, France). Samples 


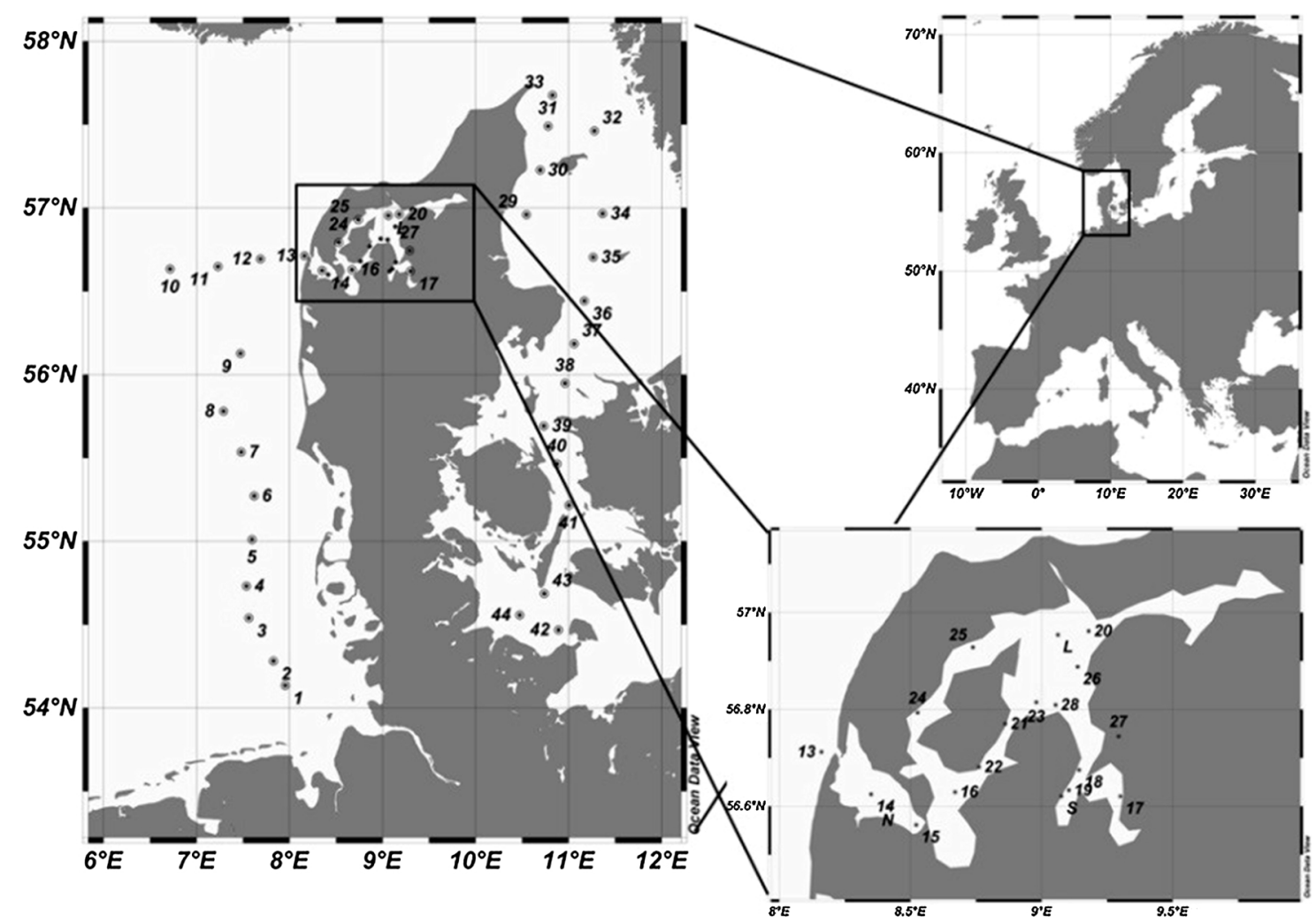

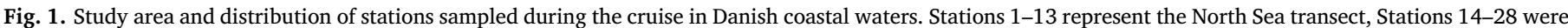

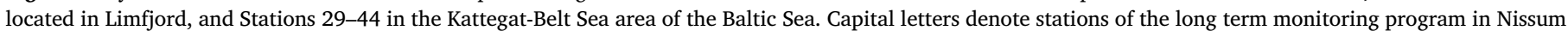
Bredning (N), Løgstør Bredning (L), and Skive Fjord (S).

were homogenized by reciprocal shaking for $45 \mathrm{~s}$ at maximal speed $\left(6.5 \mathrm{~m} \mathrm{~s}^{-1}\right)$ in a FastPrep instrument (Thermo-Savant, Illkirch, France) and subsequently centrifuged for $15 \mathrm{~min}\left(10^{\circ} \mathrm{C}, 16,100 \mathrm{x} \mathrm{g}\right)$. Supernatants were transferred into spin filters (Ultra-free, Millipore, Eschborn, Germany) and filtered by centrifugation for $30 \mathrm{~s}$ at $10{ }^{\circ} \mathrm{C}$ and $5000 \mathrm{x}$ g. Filtrates were transferred to HPLC vials and stored at $-20^{\circ} \mathrm{C}$ until analysis.

\subsubsection{Sediment samples}

In addition to water samples, sediment was collected for the determination of Alexandrium spp. resting cyst concentrations along the transect using an Ekman grab sampler. From intact pieces of surface sediment, quantitative subsamples of the uppermost $0-3 \mathrm{~cm}$ were collected using open plastic syringes and transferred into $50 \mathrm{~mL}$ centrifuge tubes. These were wrapped in aluminium foil and stored in the cold $\left(+4{ }^{\circ} \mathrm{C}\right)$ and dark until further processing. Enrichment and isolation of the dinoflagellate cyst fraction before counting followed the protocol of Bolch (1997) and included sonication, cleaning and size fractionation of $3 \mathrm{~mL}$ sediment aliquots to capture the 20 to $100 \mu \mathrm{m}$ fraction of the sediment which contains Alexandrium spp. cysts. Density gradient centrifugation was performed to concentrate and separate the organic cyst fraction from other sediment particles. The resulting material was resuspended in filtered seawater and adjusted to a defined volume for quantification of cysts.

\subsection{Toxin measurements}

Samples were tested for paralytic shellfish toxins (PST) by ion pair chromatography, post-column derivatization and fluorescence detection as previously described (Krock et al., 2007). As positive controls external standards of C1/2, GTX1/4, GTX2/3, B1, NEO and STX (Certified Reference Material programme of IMB-NRC, Halifax, NS, Canada) were run.
Lipophilic toxins were determined as described by Krock et al. (2008) with addition of for transitions for goniodomins: $m / z 786.5 \rightarrow$ 733.5 for GDA and $m / z 722.5 \rightarrow 719.5$ for GDB, respectively. Calibration solutions for $\operatorname{GDA}\left(10,50,100,500\right.$ and $\left.1000 \mathrm{pg}^{\mathrm{L}} \mathrm{L}^{1}\right)$ were prepared and used to generate an external calibration curve. External calibration was used to quantify GDA/B concentration.

Cycloimines including spirolides and gymnodimines were analysed as described in Martens et al. (2017).

\subsection{Determination of Alexandrium spp. cell and cyst abundances}

\subsubsection{Microscopy}

From selected stations, $1 \mathrm{~mL}$ of paraformaldehyde fixed net-tow samples were stained with a drop of Calcofluor-white, settled in a small sediment chamber, and analysed at 200-640 x magnification with an Axiovert 200 (Zeiss) epifluorescence inverted microscope and UV excitation. Cells of Alexandrium spp. were identified and counted based on cell shape and plate details. Whenever the ventral area of an Alexandrium cell with the first apical plate and the ventral pore was visible, cells were identified at the species level.

\subsection{2. $q P C R$ assays}

Plankton net tow samples were analysed for the presence and quantity of $A$. catenella, A. ostenfeldii and A. pseudogonyaulax 28S rDNA genes. The $>200 \mu \mathrm{M}$ size fraction was excluded from analysis. Samples were prepared essentially as described by Garneau et al. (2011). Alexandrium pseudogonyaulax -specific primers (5'-CTTGGTAAGATTGCT GCG-3', 5'-CACCCGCAAGCATTTCAC-3') were designed for this study, A. ostenfeldii-specific (5'-TTGCGTCCACTTGTGGG-3', 5'- GCAAACACA TGCATTCCAAT- $3^{\prime}$ ) and A. catenella-specific (5'-GTGTGTGTCAGGGCT TGT-3', 5'- TGTGTCTGGTGTATCTGTTTTTGT-3') primers were modified from Savela et al. (2016) and Toebe et al. (2013), respectively. Assay design was carried out following the "Minimum Information for 
Publication of Quantitative Real-Time PCR Experiments" guidelines (Bustin et al., 2009). Standards for each assay were prepared, purified and quantified as described previously by Savela et al. (2016), using the PCR reaction and thermal cycling conditions described below for each assay. Standards were produced from the following strains: X-LF-17D12, X-LF-12-F6, X-LF-19-E10 for A. pseudogonyaulax, A. catenella and A. ostenfeldii assays, respectively. All analyses were performed in triplicate on a Bio-Rad CXF96 real-time PCR instrument. Prior to analysis, sample lysates were diluted 1:100 in molecular biology grade water to avoid PCR inhibition from detergents in the lysis buffer and any inhibitory compounds in the samples. Reactions contained 1X SsoAdvanced Universal SYBR Green Supermix (Bio-Rad), either $0.3 \mu \mathrm{M}$ (A. pseudogonyaulax) or $0.5 \mu \mathrm{M}$ (A. catenella, A. ostenfeldii) of forward and reverse primers (Integrated DNA Technologies) and $2 \mu \mathrm{L}$ of 1:100 diluted sample lysate in a $10 \mu \mathrm{L}$ volume. Thermal cycling was carried out as follows: $3 \mathrm{~min}$ at $98^{\circ} \mathrm{C}, 40$ cycles of $15 \mathrm{~s}$. at $98^{\circ} \mathrm{C}$ and $60 \mathrm{~s}$. at either $56{ }^{\circ} \mathrm{C}$ (A. catenella, A. pseudogonyaulax) or $60^{\circ} \mathrm{C}$ (A. ostenfeldii) with data acquisition after each cycle, followed by the generation of a melting profile by incrementally $\left(0.5^{\circ} \mathrm{C}\right)$ increasing the temperature from $65^{\circ} \mathrm{C}$ to $95^{\circ} \mathrm{C}$. Data analysis, including automatic $\mathrm{C}_{\mathrm{q}}$ determination, was carried out using CFX Manager 3.2 software (Bio-Rad). Results from reactions in which the $\mathrm{C}_{\mathrm{q}}$ deviated for more than one cycle from their respective replicates were excluded from analysis. Further details, including assay properties and primer specificity are described in Supplementary data.

\subsubsection{Quantification of cysts from processed sediment samples}

Concentrations of Alexandrium resting cysts were analyzed using a Leica DMI3000 B inverted microscope. Three $\mathrm{mL}$ of the prepared cyst suspension was placed into an Utermöhl chamber and allowed to settle. The entire chamber was then screened at $200 \mathrm{x}$ magnification, and cysts of $A$. catenella, A. ostenfeldii and A. pseudogonyaulax were counted. While the first species can be recognized with confidence based on the typical oval-shaped appearance, size and colour were used according to the criteria of Bravo et al. (2006) and Kremp et al. (2009) to distinguish between the round and morphologically similar cysts of $A$. ostenfeldii and A. pseudogonyaulax Cysts of $A$. ostenfeldii are typically $35-40 \mu \mathrm{m}$ in size and have dark pigmentation while the size of $A$. pseudogonyaulax cysts is $>40 \mu \mathrm{m}$ and cysts are lightly pigmented.

\subsection{Statistical analyses of field data}

The non-parametric Spearman's rank correlation was used to examine correlations between the cell numbers of Alexandrium spp., $28 \mathrm{~S}$ rDNA copy numbers of $A$. pseudogonyaulax, cyst numbers of $A$. ostenfeldii, $A$. pseudogonyaulax and $A$. catenella, concentrations of GDA and spirolides, as well as total station depth, mean salinity and temperature. Salinity and temperature were averaged over the same depth as the net tows used to take plankton and toxin samples at each station. A non-parametric method was used because the data were not normally distributed. The analysis was performed using the $\mathrm{R}$ software (R Core Team 2016).

\subsection{Characterization of Alexandrium spp strains}

\subsubsection{Isolation}

At 4 stations in the North Sea and Limfjord (Table 3) a number of single Alexandrium spp. cells were isolated from live net tow samples for morphological, molecular and toxigenic characterization as described in Tillmann et al. (2014).

\subsubsection{Species confirmation of strains by $P C R$}

To confirm strain identity and for $28 \mathrm{~S}$ rDNA copy number estimation, genomic DNA was extracted from a known number of cells of strains listed in Table 3 with a DNeasy Plant Mini Kit (Qiagen) according to the instructions supplied by the manufacturer.. Cell lysis was carried out using a battery-operated motorized pestle (Kontes Glass Company). DNA yield and quality were measured spectrophotometrically (NanoDrop ND-1000) and samples were stored at $-70{ }^{\circ} \mathrm{C}$ until further analysis. Amplification of the $28 \mathrm{~S}$ rDNA gene (D1D3) was performed in reactions containing $0.5 \mu \mathrm{M}$ D1R and D3B primers (Scholin et al., 1994), manufactured by biomers.net), $0.2 \mathrm{mM}$ dNTPs (Bioline), 1X Phire HotStart buffer and $0.5 \mu \mathrm{L}$ Phire HotStart DNA polymerase (Thermo Scientific) and $1 \mathrm{ng}$ of template DNA in a total volume of $25 \mu \mathrm{L}$. Thermal cycling was carried out on a C1000 instrument (Bio-Rad) as follows: $98^{\circ} \mathrm{C} 60 \mathrm{~s}$. followed by 30 cycles of $98^{\circ} \mathrm{C} 10 \mathrm{~s}, 50{ }^{\circ} \mathrm{C} 60 \mathrm{~s}$. and $72{ }^{\circ} \mathrm{C} 60 \mathrm{~s}$. with a final extension of $72{ }^{\circ} \mathrm{C}$ for $5 \mathrm{~min}$. Amplification was confirmed on a $1.5 \% \mathrm{w} / \mathrm{v}$ agarose gel stained with 1X SYBR Safe dye (Thermo Scientific). The PCR products were subsequently excised and purified using a QIAquick Gel Extraction kit (Qiagen) following the manufacturer's protocol. All samples were submitted to Macrogen Inc. for sequencing. The resulting sequences were quality checked, edited to remove primers and aligned using UGENE 1.27.0 (Okonechnikov et al., 2012). A BLAST search (Altschul et al., 1997) was carried out to identify the obtained partial 28S rDNA gene sequences. Sequences for the strains listed in Table 3 have been submitted to GenBank under accession numbers MK441695-MK441705. Genomic 28S rDNA gene copy numbers were estimated by analysing one ng of gDNA from each isolate (with the exception of X-LF-12-C1) using the qPCR methods described above. Before analysis, DNA concentrations were determined using a QuantIt PicoGreen dsDNA kit (Thermo Fisher Scientific) according to manufacturer instructions.

\subsubsection{Toxin profiles}

Clonal isolates were grown in $200 \mathrm{~mL}$ Erlenmeyer flasks under standard culture conditions using K-medium (Keller et al., 1987), prepared from sterile-filtered natural seawater, at $15^{\circ} \mathrm{C}$, a photon flux density of $50 \mu \mathrm{mol} \mathrm{m}^{-2} \mathrm{~s}^{-1}$, and a 16:8 h light:dark photocycle. Salinity was 34 for North Sea strains and adjusted to 15 for strains originating from the Limfjord. and were harvested by centrifugation (Eppendorf 5810R, Hamburg, Germany) at $3220 \mathrm{x} g$ for $10 \mathrm{~min}$. Cell pellets were extracted with $500 \mu \mathrm{L}$ methanol by reciprocal shaking at $6.5 \mathrm{~m} / \mathrm{s}$ with $0.9 \mathrm{~g}$ lysing matrix D (Thermo Savant, Illkirch, France) in a Bio101 FastPrep instrument (Thermo Savant, Illkirch, France) for $45 \mathrm{~s}$. Extracts were then centrifuged (Eppendorf 5415 R, Hamburg, Germany) at $16,100 \times \mathrm{g}$ at $4^{\circ} \mathrm{C}$ for $15 \mathrm{~min}$. Each supernatant was transferred to a 0.45 -mm pore-size spin-filter (Millipore Ultrafree, Eschborn, Germany) and centrifuged for $30 \mathrm{~s}$ at $800 \times \mathrm{g}$, and the resulting filtrate being transferred into an autosampler vial for analysis as described above for field samples.

\subsection{Analysis of long-term Alexandrium spp. Monitoring data from Limfjorden}

Phytoplankton data for three stations situated in separate Limfjord basins (Nissum Bredning,N, Løgstør Bredning, L, and Skive Fjord, S Table S3) were extracted from the database for the Danish National Aquatic Monitoring and Assessment Program (DNAMAP), which is maintained by the Institute of Bioscience, Aarhus University, Denmark. Samples from the three stations had been analyzed for phytoplankton community composition, abundance and cell volume following the guidelines of Kaas and Markager (1998) since the late nineteen eighties. Details on the phytoplankton part of DNAMAP can be found in (Jakobsen et al., 2015). Generally, the monitoring stations have been visited one to four times per month since 1987 . However, not all stations were continuously monitored over the entire period and the station in Nissum Bredning was discontinued in 2009.

For analyses of the DNAMAP phytoplankton data, cell concentrations were $\log$ transformed, because data were not normally distributed. After the annual and monthly means were estimated, data were back-transformed. Annual summer means (May through September), as well as monthly means, were established for the period 


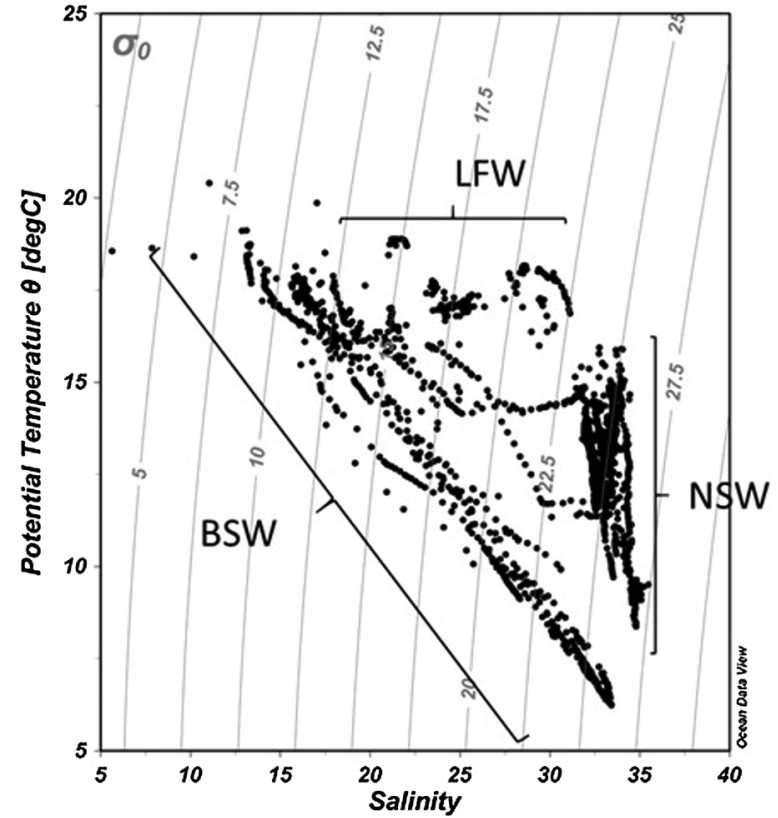

Fig. 2. Temperature and salinity conditions in the study area in June 2016, showing spatial separation of the three major sampled water masses: NSW $=$ North Sea water; LFW $=$ Limfjord water; BSW = Baltic Sea water.

from 1987 to 2015 for (1) all Alexandrium spp. observed excluding A. pseudogonyaulax and (2) for A. pseudogonyaulax only.

\section{Results}

\subsection{Hydrographic conditions}

The studied transect represented three distinct water masses, which could be identified based on salinity, temperature and density data (Fig. 2): The North Sea Water (NSW, St. 1-13) was characterized by high salinities and density, and low temperature (Fig. 2, Table 1). The Baltic Sea Water (BSW, St. 29-44) had relatively low average salinity, density and temperature despite strong gradients and wide ranges. In the Limfjord waters (LFW, St. 14-28) density and salinity were similar to the BSW, but the mean temperature was notably higher than in the two other water masses.

Depth profiles of hydrographic parameters, however, revealed more complex conditions (Fig. 3): Salinity and temperature data showed that both NSW and BSW were characterized by a strong stratification regime. In the Baltic Sea, a steep halocline at approximately $10 \mathrm{~m}$ depth separated saline and cold deep water from warm and brackish surface water. The stratification regime of NSW was dominated by temperature. The shallow Limfjord, in contrast, had a well-mixed water column.

Surface salinity decreased continuously from marine conditions in the North Sea (mean 33.3) to brackish salinities (mean 24) in the Baltic Sea where surface salinities dropped steeply across the Belt Sea from $>30$ at the entrance of the Kattegat down to a minimum of 5.6 in Kiel Bight (Table 1, Fig. 3). Salinity in the Limfjord (mean 26.1) was influenced by NSW entering the system through the narrow western boundary, and riverine freshwater discharging into the fjord. Temperatures in the shallow Limfjord and the stratified Baltic surface waters were several degrees higher than in the North Sea (Fig. 3, Table 1). High primary production as represented by Chl-a fluorescence was observed in the Limfjord (Fig. 3).

\subsection{Distribution of Alexandrium spp. cells and cysts}

\subsubsection{Cell abundances of Alexandrium spp.}

Microscopic analyses showed that Alexandrium spp. were present at 28 of the 34 analysed transect stations (Fig. 4A). Morphological analyses of calcofluor stained cells identified A. pseudogonyaulax, A. ostenfeldii and $A$. catenella in the samples, the latter, however, was only detected at two North Sea stations. The majority of encountered Alexandrium spp. cells were $A$. pseudogonyaulax. Generally, cell abundances were 10-100 times lower at the North Sea and Baltic Sea stations compared to the Limfjord, where maximum abundances of $100 \times 10^{3}$ $200 \times 10^{3}$ cells $\mathrm{NT}^{-1} \mathrm{~m}^{-1}$ were measured. These abundances correspond to approximately $1-1.5 \times 10^{3}$ cells $\mathrm{L}^{-1}$ across the entire water column. Highest abundances occurred at St. 25 in the central Limfjord and at St. 17-19 and 27 in the shallow brackish Skive Fjord basin.

Dominance of $A$. pseudogonyaulax was confirmed by qPCR results (Supplementary Table S4): copy numbers of A. pseudogonyaulax 28S rDNA correlated significantly with Alexandrium spp. cell counts. Molecular identification revealed presence of $A$. ostenfeldii at stations 17, 18 and 20 in the central Limfjord and in the Skive Fjord basin (Table S4). However, 28S rDNA copy numbers remained below reliable quantification levels. A. catenella was identified from 10 of the 44 analyzed stations by qPCR. These were mostly located in the North Sea and the western parts of the Limfjord. Quantifiable, but low amounts, compared to A. pseudogonyaulax, occurred at St. 11 and 12 in the North Sea. At all other positive stations, only traces were detected. The high abundance of $A$. pseudogonyaulax, quantified by $28 \mathrm{~S}$ rDNA copy numbers, correlated with low depth, low salinity and high temperature (Spearman's rank correlation, $\mathrm{p}<0.02$ for all) as shown in Table 2 .

\subsubsection{Distribution of resting cysts}

Resting cysts of $A$. pseudogonyaulax, A. ostenfeldii and A. catenella were detected in all studied sea areas (Fig. 4B-D). Their distribution was patchy in the North Sea and restricted to the Kattegat area in the Baltic Sea (Stations 29-39) except A. ostenfeldii, which was also prevalent in Kiel Bight (Station 42) sediments. Similar to cell distribution in plankton samples, cysts occurred more frequently in the Limfjord sediments and generally had higher concentrations here compared to the North Sea and Baltic Sea. Like cell concentrations, highest cyst concentrations were found in Skive Fjord (S). In contrast to cell abundances, cyst numbers of $A$. pseudogonyaulax and $A$. ostenfeldii were in the same range. A. catenella cysts were less abundant in the Limfjord than cysts of the two other Alexandrium species. In the Baltic Sea, A. catenella cysts were only seen at St. 31, one of the northernmost marine stations sampled in the Kattegat. Generally, in stations where cysts accumulated, cyst concentrations of all three species were high (Fig. 4). For A. ostenfeldii and A. pseudogonyaulax cysts, a negative correlation was found between depth and cyst concentrations (Table $2, \mathrm{p}<0.05$ ).

Table 1

Mean and standard deviation of major oceanographic variables depth, salinity, temperature and density characterizing the different water masses studied during the survey: North Sea, Limfjord and Baltic Sea. Values in brackets represent measured ranges.

\begin{tabular}{|c|c|c|c|c|c|}
\hline & n Stations & depth & Salinity & Temperature & Density \\
\hline North Sea & 13 & $27.35 \pm 7.20$ & $33.3 \pm 0.9(30.2 ; 35.5)$ & $12.48 \pm 1.79(8.38 ; 16.54)$ & $25.13 \pm 0.90(21.94 ; 27.41)$ \\
\hline Limfjord & 15 & $9.11 \pm 2.6$ & $26.07 \pm 2.47(17.71 ; 32.71)$ & $17.38 \pm 0.56(14.20 ; 18.89)$ & $18.59 \pm 1.87(12.47 ; 24.18)$ \\
\hline Baltic Sea & 16 & $26.10 \pm 13.4$ & $24.49 \pm 7.45(5.53 ; 33.68)$ & $13.47 \pm 3.93(6.24 ; 20.41)$ & $18.13 \pm 6.33(2.78 ; 26.27)$ \\
\hline
\end{tabular}



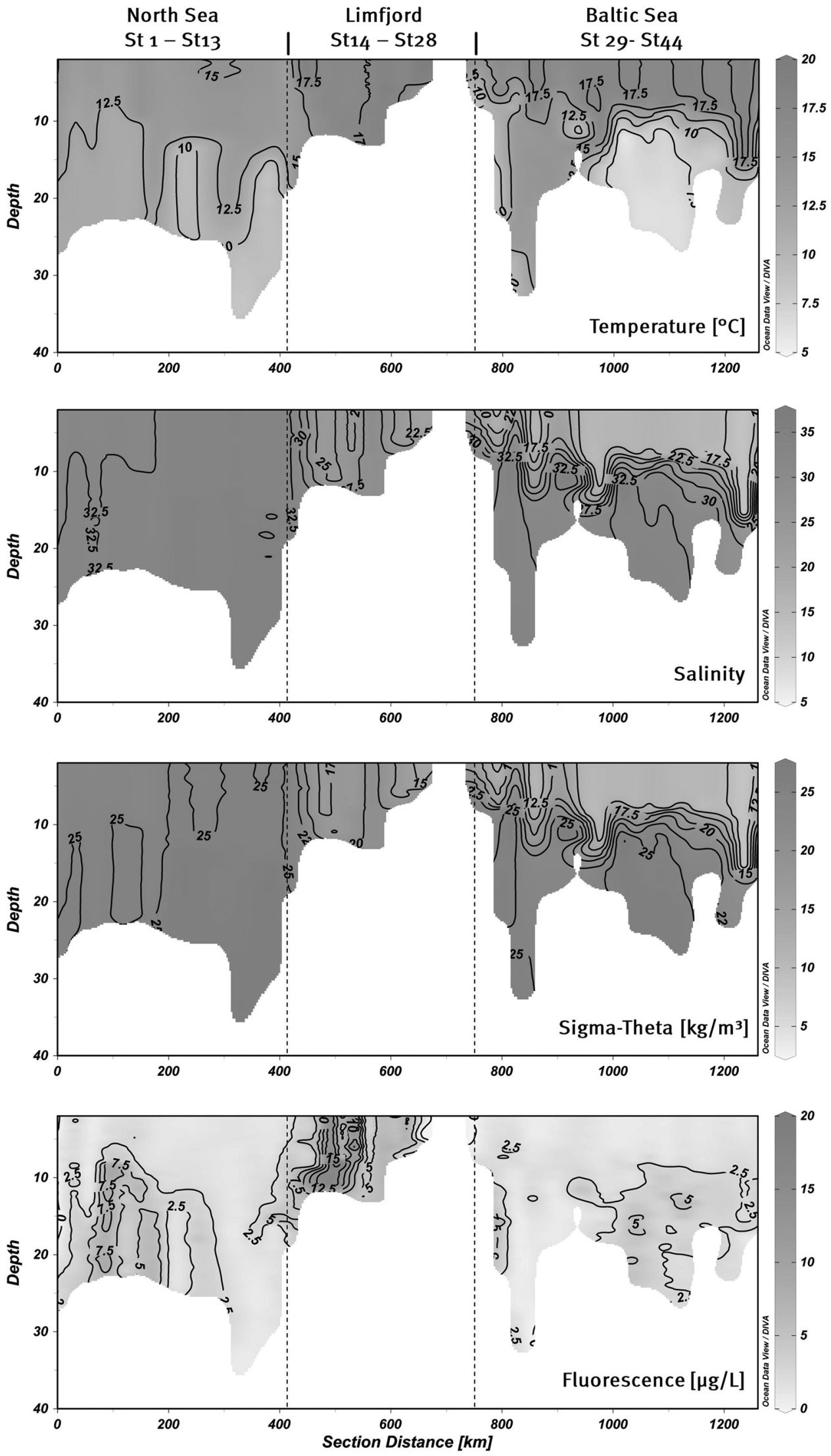

Fig. 3. Depth profiles of salinity, density, temperature $\left({ }^{\circ} \mathrm{C}\right)$ and Chla fluorescence $\left(\mu \mathrm{L}^{-1}\right)$ across the sampled transect. Profiles start at Station 1 in the German Bight /North Sea and end at Station 44 in Kiel Bight, Baltic Sea. 

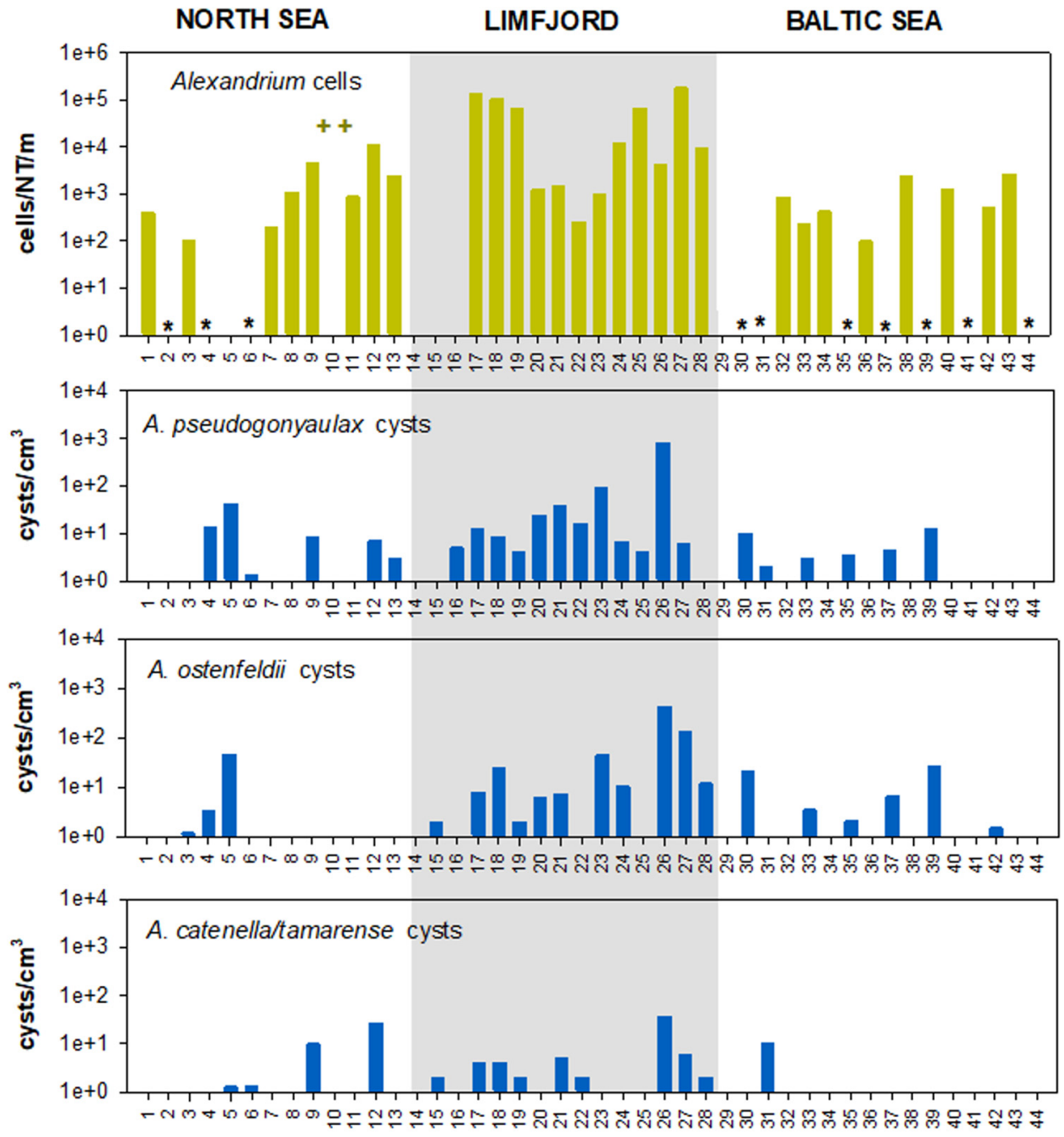

Station Number

Fig. 4. Alexandrium spp. cells and cysts across the North Sea - Baltic Sea transect. Cell numbers were calculated from net tows integrating the water column (A). Cyst concentrations of A. pseudogonyaulax (B), A. ostenfeldii (C) and A. catenella (D) at the sediment surface. Stations indicated with an asterisk were not analyzed for cell abundances. Stations marked with a green cross represent the presence of $A$. catenella (For interpretation of the references to colour in this figure legend, the reader is referred to the web version of this article).

\subsection{Toxin distribution}

\subsubsection{Goniodomins}

Goniodomin A was the most abundant toxin measured in the study area at the time of the survey. It was detected in all three investigated water bodies: North Sea, Limfjord and Baltic Sea (Fig. 5). Though GDA was detected at most sampled stations in the $20-50 \mu$ m plankton fraction, amounts of this toxin varied widely throughout the studied transect. High levels of GDA were found in the Limfjord (up to $590 \mathrm{ng}$ $\mathrm{NT}^{-1} \mathrm{~m}^{-1}$ ), whereas GDA in the North Sea and the Kattegat remained mostly below $100 \mathrm{ng} \mathrm{NT}^{-1} \mathrm{~m}^{-1}$ (Fig. 5). GDA was not detected in the German Bight but appeared at the Stations between Sylt Island and the western entrance of the Limfjord (Stations 6-13). While in the Kattegat hardly any GDA was detected, abundances comparable to the North Sea were measured further south in the Great Belt and Kiel Bight area (Stations 39-44). GDA concentrations were positively correlated with both Alexandrium spp cell numbers and 28S copy numbers of A. pseudogonyaulax ( $\mathrm{p}<0.001$ for both, Table 2 ).

Table 2

Spearman's rank correlation, $\mathrm{r}_{\mathrm{s}}$ values. Significant correlations $(\mathrm{p}<0.05)$ in bold. A pse $=$ A. pseudogonyaulax; A. ost $=$ A.ostenfeldii, A. cat $=$ A. catenella .

\begin{tabular}{llllllll}
\hline & Depth & Salinity & Temperature & A.pse 28S rDNA copies & A.ost cysts & A.pse cysts & A.cat cysts \\
\hline Salinity & $\mathbf{0 . 3 8}$ & & & & & & \\
Temperature & $-\mathbf{0 . 7 5}$ & $-\mathbf{0 . 4 8}$ & & & & \\
A.pse 28S rDNA copies & $-\mathbf{0 . 4 1}$ & $-\mathbf{0 . 4 1}$ & $\mathbf{0 . 4 1}$ & & & \\
A.ost cysts & $-\mathbf{0 . 3 1}$ & -0.15 & 0.08 & 0.14 & $\mathbf{0 . 6 2}$ & \\
A.pse cysts & -0.26 & 0.21 & 0.05 & 0.19 & $\mathbf{0 . 4 0}$ & $\mathbf{0 . 5 6}$ \\
A.cat cysts & -0.22 & 0.22 & 0.18 & 0.21 & -0.04 & 0.06 & 0.05 \\
GDA & -0.11 & -0.30 & 0.14 & $\mathbf{0 . 7 3}$ & 0.11 & 0.28 & $\mathbf{0 . 5 0}$ \\
SPX total & -0.12 & $\mathbf{0 . 5 3}$ & 0.00 & 0.08 & & 0.00
\end{tabular}


Table 3

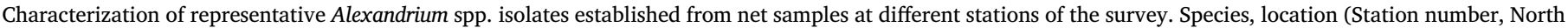
Sea/Limfjord/Baltic Sea, coordinates), toxin composition, GenBank accession number.

\begin{tabular}{|c|c|c|c|c|c|c|c|c|}
\hline Species & Strain & Origin Station & Length $(\mu \mathrm{m})$ & $\begin{array}{l}\text { Width }(\mu \mathrm{m}) \\
\text { Mean } \pm \text { SD Min-max }\end{array}$ & $\begin{array}{l}1 / \mathrm{w} \text { ratio } \\
\text { Mean } \pm \mathrm{SD}\end{array}$ & $\mathrm{N}$ & Accession number & Toxins \\
\hline A. pseudogonyaulax & X-LF-12-B4 & 12 & $\begin{array}{l}37.0 \pm 2.9 \\
31.3-43.3\end{array}$ & $\begin{array}{r}35.7 \pm 3.5 \\
28.4-44.7\end{array}$ & $1.04 \pm 0.05$ & 50 & MK441698 & GDA \\
\hline A. pseudogonyaulax & X-LF-12-D1 & 12 & $\begin{array}{l}39.6 \pm 3.5 \\
33.4-52.2\end{array}$ & $\begin{array}{r}37.4 \pm 4.4 \\
31.3-50.8\end{array}$ & $1.06 \pm 0.05$ & 50 & MK441699 & GDA/B \\
\hline A. pseudogonyaulax & X-LF-19-D12 & 19 & $\begin{array}{l}35.9 \pm 2.8 \\
30.3-44.1\end{array}$ & $\begin{array}{r}34.7 \pm 2.6 \\
29.1-39.9\end{array}$ & $1.03 \pm 0.05$ & 47 & MK441702 & GDA \\
\hline A. pseudogonyaulax & X-LF-19-F5 & 19 & $\begin{array}{l}35.4 \pm 5.2 \\
27.7-50.6\end{array}$ & $\begin{array}{r}35.4 \pm 5.3 \\
26.6-49.5\end{array}$ & $1.00 \pm 0.06$ & 50 & MK441703 & GDA/B \\
\hline A. pseudogonyaulax & X-LF-17-H10 & 17 & $\begin{array}{l}37.5 \pm 5.6 \\
28.6-51.6\end{array}$ & $\begin{array}{r}35.2 \pm 5.9 \\
25.1-48.1\end{array}$ & $1.07 \pm 0.06$ & 53 & MK441701 & GDA/B \\
\hline A. pseudogonyaulax & X-LF-17-D12 & 17 & $\begin{array}{l}39.7 \pm 4.5 \\
30.7-50.9\end{array}$ & $\begin{array}{r}38.0 \pm 5.1 \\
28.8-49.7\end{array}$ & $1.05 \pm 0.07$ & 52 & MK441700 & GDA/B \\
\hline A. pseudogonyaulax & X-LF-27-G4 & 27 & - & - & - & - & MK441704 & GDA/B \\
\hline A. catenella & X-LF-12-F9 & 12 & $\begin{array}{l}29.4 \pm 1.9 \\
26.4-39.4\end{array}$ & $\begin{array}{r}30.4 \pm 1.5 \\
27.5-34.8\end{array}$ & $0.97 \pm 0.05$ & 54 & MK441695 & PST \\
\hline A. catenella & X-LF-12-F6 & 12 & - & - & - & - & MK441696 & PST \\
\hline A. ostenfeldii & X-LF-19-E10 & 19 & $\begin{array}{l}35.6 \pm 5.7 \\
23.3-51.2\end{array}$ & $\begin{array}{r}34.3 \pm 5.8 \\
22.5-49.5\end{array}$ & $1.04 \pm 0.05$ & 103 & MK441697 & SPX, GYM \\
\hline A. ostenfeldii & X-LF-19-F10 & 19 & $\begin{array}{l}38.3 \pm 5.4 \\
26.4-52.6\end{array}$ & $\begin{array}{r}37.8 \pm 5.0 \\
25.8-49.1\end{array}$ & $1.01 \pm 0.04$ & 104 & - & SPX, GYM \\
\hline A. tamutum & X-LF-12-C1 & 12 & $\begin{array}{l}27.1 \pm 2.6 \\
21.2-32.4\end{array}$ & $\begin{array}{r}25.9 \pm 2.5 \\
21.0-30.0\end{array}$ & $1.05 \pm 0.04$ & 40 & MK441705 & ND \\
\hline
\end{tabular}

\subsubsection{Cycloimines}

Spirolides (SPX) were present in most samples of the $20-50 \mu \mathrm{m}$ plankton fraction, collected along the transect (Fig. 6). Their abundances, however, were several magnitudes lower than GDA at most of the stations. SPX profiles consisted of 4 different compounds: spirolide G (SPX-G), 13-desmethyl spirolide C (SPX1), 13,19didesmeSPX-C and 20meSPX-G which contributed differently to the profiles depending on the water body. In the North Sea and the Kattegat areas, 20meSPX-G dominated the profile, followed by SPX1, 13,19didesmeSPX-C and traces of SPX-C. The SPX composition was reverse in the Limfjord with SPX-G being the dominant fraction and low levels of 20-meSPX-G. Spirolide abundances were generally higher in the Limfjord compared to the North Sea and the Baltic Sea. In the Baltic Sea, south of the Kattegat (Belt Sea and Kiel Bight, Stations 39-44) spirolides occurred at low abundances, hardly ever exceeding $10 \mathrm{pg} \mathrm{NT}^{-1} \mathrm{~m}^{-1}$. Gymnodimines (GYM) were absent from North Sea samples but occurred in the eastern Limfjord basin (Skive Fjord, S) together with SPX-G, SPX1 and 13,19didesmeSPX-C. Although no significant correlation was found between SPX and A. ostenfeldii cyst abundances, SPX distribution was related to salinity ( $\mathrm{p}<0.001$, Table 2 ).

\subsubsection{PST}

PST was only detected at stations 9,11 and 12 in the North Sea. PST abundances at these three stations were generally low, but increased from station 9 to 12 and consisted of $\mathrm{C} 1 / 2(13.9,15.2$ and $21.5 \mathrm{ng}$ $\mathrm{NT}^{-1} \mathrm{~m}^{-1}$ ), GTX2/3 (7.7, 9.3 and $10.3 \mathrm{ng} \mathrm{NT}^{-1} \mathrm{~m}^{-1}$ ), NEO (nd, 7.5 and $8.8 \mathrm{ng} \mathrm{NT}^{-1} \mathrm{~m}^{-1}$ ) and STX $\left(6.0,6.9\right.$ and $\left.8.2 \mathrm{ng} \mathrm{NT}^{-1} \mathrm{~m}^{-1}\right)$.

\subsection{Characteristics of Alexandrium spp. strains}

Identities of Alexandrium spp. strains isolated at St. 12 (North Sea), 17, 19 and 27 (Skive Fjord, Limfjord, S in Fig. 1) confirmed the distribution of the different species in field samples. From the Limfjord stations, the majority of strains were identified as A. pseudongonyaulax, and only two strains of $A$. ostenfeldii were established from Station 19 in the strongly freshwater influenced innermost bay of Skive Fjord. The marine Station 12 yielded two A. pseudogonyaulax strains, two saxitoxin-producing A. catenella (previously $A$. tamarense complex group 1) strains and one non-toxic A. tamutum strain (Table 3 )

All Limfjord A. pseudogonyaulax strains had nearly identical $28 \mathrm{~S}$ rDNA sequences (> 99\% identity), and were likewise genetically indistinguishable from global A. pseudogonyaulax strains, including a previously sequenced strain from Oslofjord (JF521638). The extremely low sequence variation among the few available $28 \mathrm{~S}$ rDNA sequences did not provide phylogenetic resolution. The 28S rDNA genomic copy number in A. pseudogonyaulax strains was estimated to vary between 81 000 and 703000 per genome. The successfully analysed sequence of $A$. ostenfeldii strain X-LF-19-E10 (Accession number MK441697) was identical to 28S rDNA sequences from strains K0289 (AJ535356) and CCMP1773 (JF521636), which were both obtained from the same area 30 years ago. The genome of X-LF-19-E10 contained an estimated 2500 copies of the $28 \mathrm{~S}$ rDNA gene, comparable to previous observations from

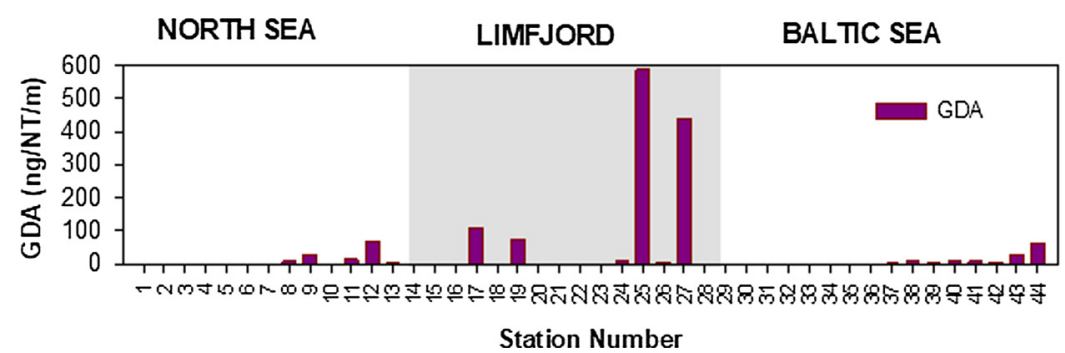

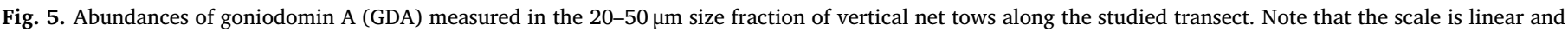
lower values may not be visible. GDA abundances were normalized to net tow per meter of water column (NT m ${ }^{-1}$ ). 


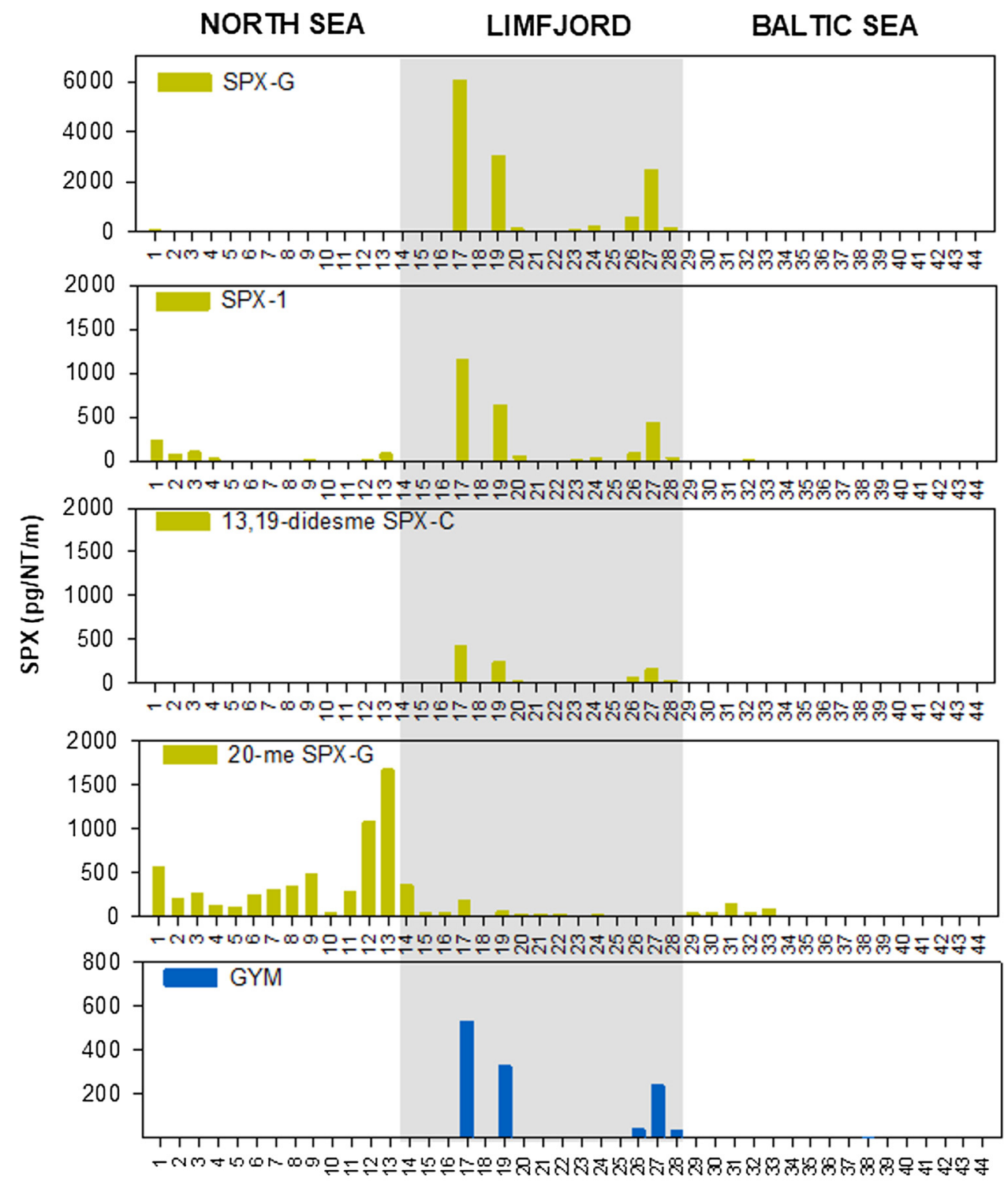

Station Number

Fig. 6. Abundances of cycloimines measured in the $20-50 \mu \mathrm{m}$ size fraction of vertical net tows along the studied transect.

Baltic Sea A. ostenfeldii (Savela et al., 2016). The 28S rDNA copy numbers of the two A. catenella varied from 6900 to 43000 per genome, and the sequences closely matched strains assigned to the $A$. tamarense complex Group I, including strains isolated from the east coast of North America, Scottish and English waters (Fig. S3)

Size ranges of $A$. pseudogonyaulax were large (Table 3, Fig. 7A-J) although average cell sizes were slightly lower than typical for the species, overlapping with $A$. ostenfeldii. Cell shapes ranged from slightly compressed to round (Fig. 7A, B, F, G). The compressed appearance typical for the species was only found in a few strains. Growing cultures of all strains contained characteristic division cysts (Fig. 7H). The plate patterns visualized by calcofluor staining were typical for $A$. pseudogonyaulax (Fig. 7C-E and I, J): The first apical plate (1') was disconnected from the pore (po) plate (Fig. 7C and I) and the large sp plate was laterally compressed (Fig. 7D and J). A. catenella cells of the examined strain Z-LF-12-F9 (Fig. 7K-M) were relatively small (Table 3) and in exponentially growing cultures often appeared in couplets (Fig. 7L) or 4-cell chains. A ventral pore was present on the right margin of the first apical plate (Fig. 7M). The two Alexandrium ostenfeldii strains from the Limfjord St. 19 were in the same size range as $A$. pseudogonyaulax (Table 3) and were mostly round (Fig. 7N). Patterns and shapes of their thecal plates were as described earlier of the Limfjord strains: the 1 ' plates were narrow and had a large ventral pore and cells predominantly contained door-latch shaped s.a. plates (Fig. 70).

The toxin composition of $A$. pseudogonyaulax strains is extensively presented in Krock et al. (2018). The isolates characterized here contained predominantly goniodomin A (GDA), but goniodomin B (GDB) was also detected in all cultures from both water bodies. Other toxins (PST, spirolides or gymnodimines) could not be detected. A. catenella cultures had complex PST profiles, containing C1/C2, GTX2/3, GTX1/ 4, B1, NEO and STX but the cellular amounts were low and PST composition varied among the two established strains from station 12 (Fig. 8). A. ostenfeldii strains, including CCMP1773 isolated from the same area in 1987 by Hansen et al. (1992), did not produce PST, but spirolides and gymnodimines A (GYM A) (Fig. 8). While the two new isolates (X-LF-19-E10 and F10) contained mainly SPX-G, CCMP1773 had 13,19-didesme SPX-C besides SPX-1. Cell quotas varied among the investigated strains.

From North Sea station 12 one strain of $A$. tamutum was established. 


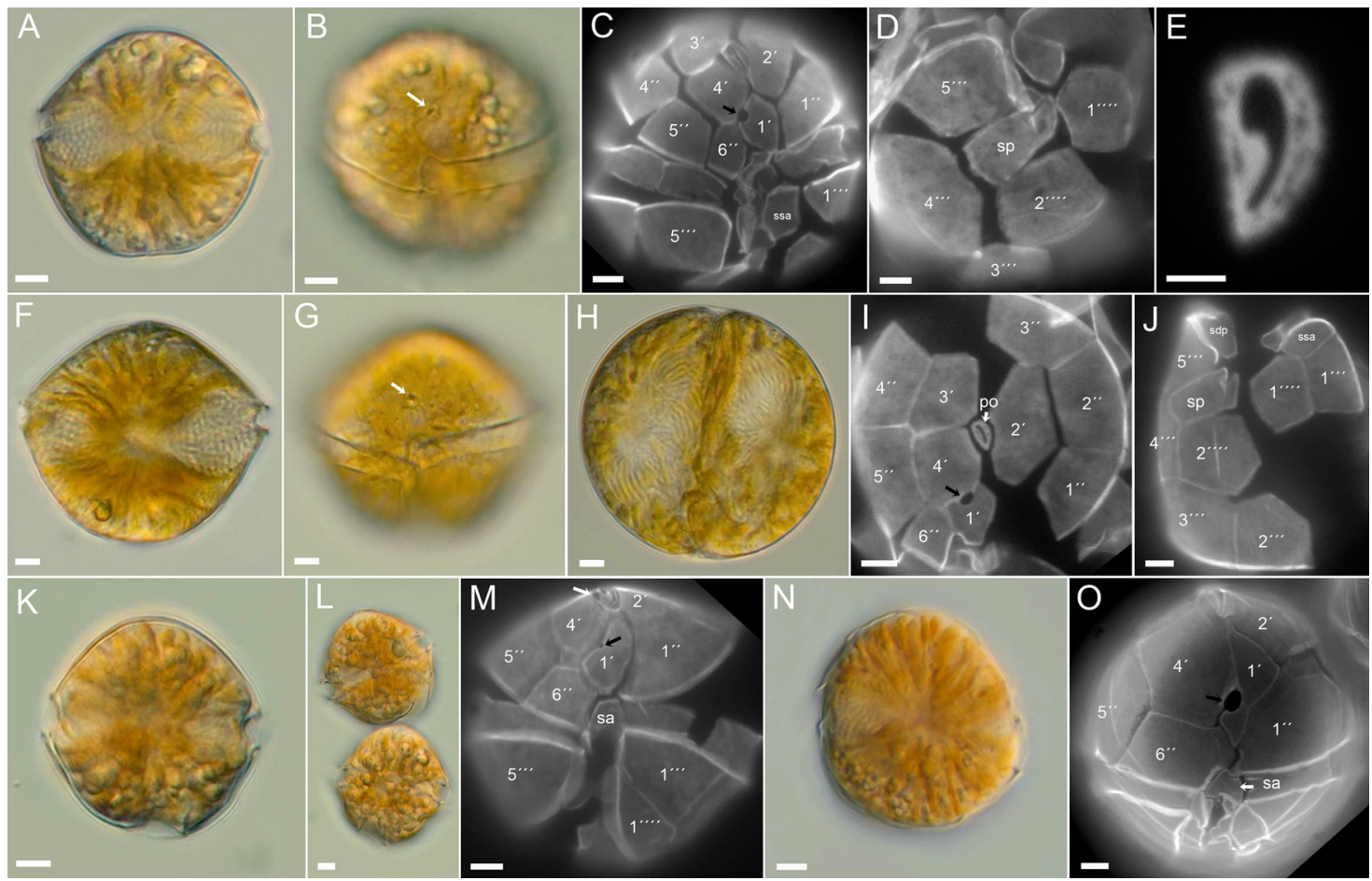

Fig. 7. Morphology of A. pseudogonyaulax strains X-LF-17-H10 (A-E) and X-LF-19-F5 (F-J) isolated from Limfjord, and Alexandrium catenella X-LF-9-F9 (K-M) from the North Sea, and A. ostenfeldii X-LF-19-E10 (N-O from Limfjord). Scale bar $=5 \mu \mathrm{m}$ (except E $=2 \mu \mathrm{m}$ ).

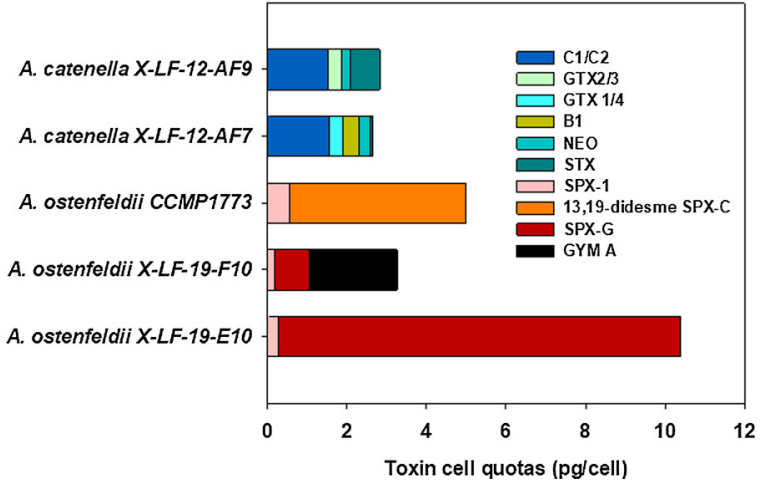

Fig. 8. Toxin profiles of $A$. catenella (PST) and A. ostenfeldii (cycloimines) isolates.

The identity of the strain, suggested by morphological characters was confirmed by $28 \mathrm{~S}$ rDNA sequence data. Cells of this strain were distinctly smaller than the other three species. No toxins were detected in this strain.

3.5. Long-term seasonal and annual dynamics of Alexandrium spp. and A. pseudogonyaulax in Limfjorden

The monitoring data document that Alexandrium spp. have been present in the Limfjord since 1987 at least (Fig. 9A). The highest annual

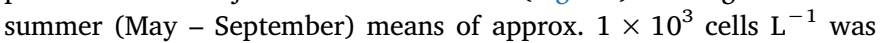
measured in 1987. Typically, abundances, ranged between 0.2 and $0.4 \times 10^{3}$ cells L $^{-1}$ until 2009 after which Alexandrium spp. (excluding A. pseudogonyaulax) disappeared from the Limfjord monitoring samples (Fig. 9A). In the summer of 2007, A. pseudogonyaulax was observed for the first time in monitoring samples at abundances of $0.1 \times 10^{3}$ cells $\mathrm{L}^{-1}$. In the following two years, peak abundances of this species reached $3.0-3.5 \times 10^{3}$ cells $\mathrm{L}^{-1}$ and afterwards the annual summer mean declined and reached $0.7 \times 10^{3}$ cells $\mathrm{L}^{-1}$ in 2015 .
The monthly mean cell concentrations of Alexandrium spp. excluding A. pseudogonyaulax during 1987-2007 increased from zero in February to around $0.4 \times 10^{3}$ cells $\mathrm{L}^{-1}$ in April (Fig. 9B). From April and until November Alexandrium spp. concentration was constant at $0.4 \times 10^{3}$ cells $\mathrm{L}^{-1}$. The highest concentrations were typically recorded between July and September. The monthly mean of A. pseudogonyaulax (Fig. 9C) during 2007-2015 was low in April and May but increased drastically to values between of 3.5 and $5 \times 10^{3}$ cells $\mathrm{L}^{-1}$ in June through September where-after abundance dropped to $0.2 \times 10^{3}$ cells $\mathrm{L}^{-1}$ in October and was not detected during winter (Fig. 9C). Alexandrium spp. had a wider temporal distribution than A. pseudogonyaulax, and highest monthly means were 10 fold higher for A. pseudogonyaulax compared to Alexandrium spp.

\section{Discussion}

4.1. Low salinity, high temperature and proximity to seed "banks" favor Alexandrium pseudogonyaulax in the Limfjord, Denmark

The observed differences in Alexandrium abundances and toxins along the studied transect coincide with the boundaries separating the three major water masses. Differences were particularly pronounced between the shallow well-mixed brackish Limfjord and the adjacent deep and stratified sea areas. Throughout the Limfjord high abundances of goniodomin A (GDA) and A. pseudogonyaulax cell and DNA copy numbers were encountered which significantly correlated with high temperature, low salinities and low depth prevailing in the fjord system at the time of sampling. Alexandrium pseudogonyaulax has previously been mostly reported from warm water environments (Biecheler, 1952; Honsell et al., 1992; Montresor, 1995; Bravo et al., 2006; Zmerli Triki et al., 2014) and thus the high water temperature found in the shallow sheltered Limfjord basins at the time of sampling likely favoured growth of this species here. Being an estuarine species, which often seems to be associated with decreased salinities (Balech, 1995), A. pseudogonyaulax can be expected to tolerate the brackish conditions in the Limfjord very well. In Bizerte lagoon, Tunisia, where the species has 

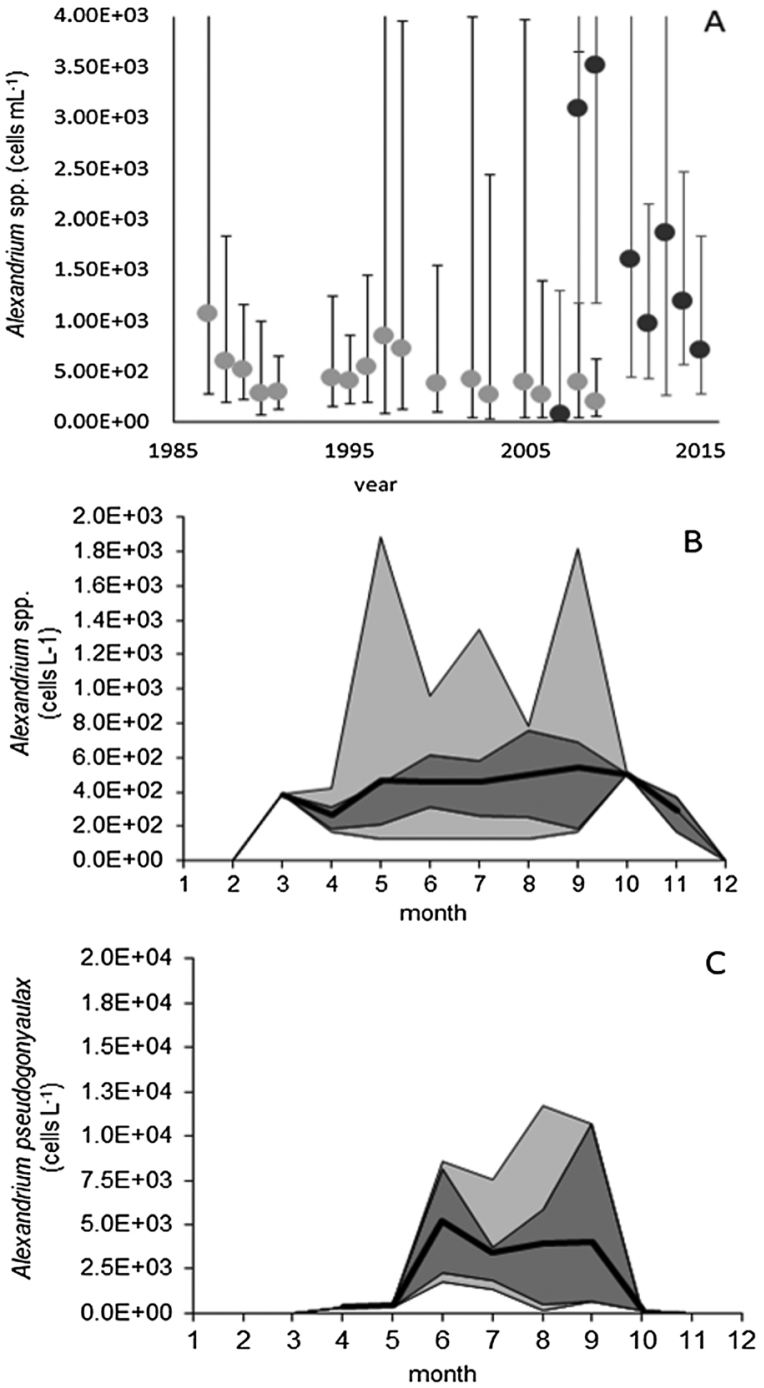

Fig. 9. A) Summer abundances (cells $\mathrm{L}^{-1}$ ) of Alexandrium spp and Alexandrium pseudogonyaulax since 1987 at the DNAMAP monitoring stations in Limfjorden. Grey circles represent Alexandrium spp. and black circles are abundances of Alexandrium pseudogonyaulax. Error bars are standard errors of the mean. Due to data being lognormal distributed, the "positive" error bars are higher than the "negative" error bars. B) Monthly mean concentrations (cells $\mathrm{L}^{-1}$ ) of Alexandrium spp. excluding Alexandrium pseudogonyaulax of the three DNAMAP monitoring stations in Limfjorden. Full black line is the mean for the period 1987-2007, Light grey displays the variation, and dark grey are the upper and lower quartiles. C) Monthly mean concentrations (cells $\mathrm{L}^{-1}$ ) Alexandrium pseudogonyaulax of the three DNAMAP monitoring stations in Limfjorden. Full black line is the mean for the period 2007 - 2015. Light grey display the variation, and dark grey are the upper and lower quartiles.

been studied extensively, a wide salinity tolerance span was detected (Zmerli-Triki et al. 2015).

North Atlantic Alexandrium catenella generally prefers cooler water (Etheridge and Roesler, 2005; Eckford-Soper et al., 2016), which may explain why this species was only detectable in colder North Sea water and not in the Limfjord or the Baltic Sea in this survey. With regard to salinity, many Alexandrium species prefer estuarine environments and have optimal growth rates at around 25-30 psu (Etheridge and Roesler, 2005; Bill et al., 2016). Depending on the environments they are adapted to and even thrive at salinities $<15$ psu (Suikkanen et al., 2013a, Martens et al., 2016). Also for A. ostenfeldii from the Limfjord wide salinity tolerance spans matching the conditions of this water body have been confirmed previously, as well as a preference for warm water (Østergaard-Jensen and Moestrup, 1997). It is unclear why $A$. ostenfeldii was so much less abundant than A. pseudogonyaulax when Limfjord was sampled, despite so similar temperature and salinity adaptations. It could be speculated that the general increase of temperature in the system (Hansen, 2018) opened a niche for the invasion of $A$. pseudogonyaulax at the cost of A. ostenfeldii. However, it needs to be noted that this study covered only a very short period that may have been insufficient for a comprehensive understanding of the situation.

In this study, Alexandrium cell and 28S rDNA copy numbers were negatively correlated with water depth, i.e. highest values were associated with low depth. This observation concurs with data on the distribution of Alexandrium cells in Danish waters as determined by the national algal monitoring program (Hans $\mathrm{H}$. Jakobsen, personal communication, Table S3). The shallow depth of the Limfjord system provides an important advantage for Alexandrium compared to the North Sea and the Baltic Sea- proximity to seed banks due to relatively low water depth. Like most Alexandrium species, also the three species studied here form resistant resting cysts to survive unfavourable conditions (Anderson, 1998; Montresor, 1995; MacKenzie et al., 1996). Their resting cysts were present in all three water bodies, but at notably higher concentrations in the Limfjord. The significant correlation between cyst concentrations of the three Alexandrium species suggests that cyst accumulation hot spots exist in the different sampled Limfjord basins. Particularly high cyst numbers were found in the shallow and sheltered Skive Fjord basin (max depth $8 \mathrm{~m}$ ), where strong benthicpelagic coupling has been documented previously (Krause-Jensen et al., 2012). For Alexandrium, a shallow water column in a sheltered water body provides optimal conditions for recruitment from the "seed bank" represented by cyst accumulations: light can penetrate to the bottom and stimulate germination (Zmerli Triki et al., 2015). Having access to light, germinated cells, in turn, can resume growth immediately and have a better chance to form blooms than cells germinated in deep water. Thus, sizeable cyst deposits together with low water depth should support successful recruitment and bloom formation in the Limfjord.

Although the high cyst concentrations in the separate Limfjord basins are likely a result of accumulation due to local bloom retention, the major current patterns prevailing at the Danish coasts might promote cyst deposition in the fjord. Northwards flowing water masses carrying Alexandrium cells from the English Channel and the southern North Sea (Aure et al., 1998; Gyllencreutz et al., 2006) up the Danish west coast during spring are pushed eastwards in the area of Jutland due to dominating westerly winds (Møller, 1996). As this interplay between the major current and wind directions control the water exchange in the Limfjord, and inflowing Alexandrium cells may conclude their life cycles here. The resulting resting cysts are deposited in bottom sediments of the Limfjord, where they add to the Alexandrium seed banks.

Abundances of $A$. ostenfeldii cysts as identified here where generally in the same range as $A$. pseudogonyaulax and again it remains unclear why proximity to dense cyst deposits should only favour A. pseudogonyaulax, but not $A$. ostenfeldii despite their similar habitat preferences and effective germination strategies at higher water temperature and in the presence of light (Østergaard-Jensen and Moestrup, 1997; Gu, 2011, Zmerli Triki et al., 2015). It is possible that $A$. ostenfeldii cyst abundances were overestimated because the generally smaller cysts of $A$. ostenfeldii overlap to some extent with the generally larger cysts of $A$. pseudogonyaulax. Limfjord A. pseudogonyaulax cells seem to be generally smaller than the species' average size (see below) thus the overlap might have been higher than expected. Alternatively, A. ostenfeldii cyst deposits could represent old stocks reminiscent of the period before 2009 when A. ostenfeldii abundances declined in monitoring observations (Fig. 9).

The characteristically elongated cysts of Alexandrium catenella where found in low abundances at many stations in the North Sea and in the Limfjord confirming that a seed stock for toxic blooms of this species is present here. In the Baltic Sea, these cysts were only recorded at one of the northernmost marine influenced stations in Kattegat. This 
is in line with the preference for higher salinities as compared to A. ostenfeldii and pseudogonyaulax.

\subsection{High goniodomin abundances and specific cycloimine profiles, but no PST in the Limfjord}

The distribution pattern of the three Alexandrium species in the plankton was reflected by toxin patterns. Goniodomin abundances mirror cell abundance patterns with highest values in Skive Fjord where also highest cell numbers of A. pseudogonyaulax were encountered. Cycloimines, on the other hand, were found at many stations where cell and DNA copy numbers of $A$. ostenfeldii remained below detection level. This discrepancy may reflect sensitivity differences between both toxin groups. Whereas cycloimines are detected very sensitively by mass spectrometry due to the easy ionization of the imino function, pure polyketides without any preferred ionization site such as goniodomins are detected with much less sensivity.

In this study, the cycloimine data provided interesting additional information on A. ostenfeldii distribution. Cycloimines were present in all three water bodies, at nearly all stations, indicating that also $A$. ostenfeldii occurred throughout the entire transect. The cycloimine composition was unique in the Limfjord. While in the North Sea and Baltic Sea 20me-SPX-G were dominant and no GYM A was detected (except for Stn 38 in the Baltic Sea), Limfjord samples had diverse spirolide profiles containing significant proportions of all measured spirolides and GYM A, but no $20 \mathrm{meSPX}-\mathrm{G}$. The pattern was consistent at all stations with measurable amounts of cycloimines, suggesting that the Limfjord population of $A$. ostenfeldii has evolved specific toxin profiles or that the specific prevailing conditions affect toxin profiles.

Salinity is one factor to consider in this context as the condition that changed considerably along the transect and salinity was positively correlated with total amounts of SPX. Nevertheless, relating the toxin composition to salinity is not straightforward. The observed differences between the North Sea and the Limfjord were not the same as in the Baltic Sea. The northern stations of the Baltic Sea had the same brackish salinities as the Limfjord, but cycloimine patterns were similar to those observed in marine waters of the North Sea. Toxin profiles are generally strain-specific and stable in their composition, but the relative proportion of the different derivatives can vary at different salinities in Alexandrium ostenfeldii (Suikkanen et al., 2013a). One could thus hypothesize that salinity directly influenced the amounts of specific derivatives along the salinity gradient, but again, the observed differences are not consistent along the sampled gradient. Martens et al. (2017) found a large variability of cycloimine profiles and cell quotas among single strains isolated from a brackish water population of $A$. ostenfeldii. It is possible that other conditions than salinity, e.g. competition or grazer regimes, lead to the selection of genotypes with consistently different toxin profiles in the Limfjord. Such environmental geno- and/ or phenotype selection has recently been documented for diatoms (Godhe et al., 2016; Sjöqvist and Kremp, 2016).

PSTs were only found on rare occasions in plankton field samples at three North Sea stations. The concentrations of A. catenella in North Sea water were too low for more frequent PST detection. Interestingly the PST profiles at the three stations resembled the toxin profile of $\mathrm{A}$. $\mathrm{Ca}$ tenella strain X-LF-12-AF9 isolated from St. 12 containing C1/2, GTX2/ 3 , NEO and STX, whereas the other strain (X-LF-12-AF7) isolated from the same station produced $\mathrm{C} 1 / 2$, B1 and GTX1/4 as major PST variants. This is a clear evidence for different strains contributing in different amounts to a field population of a given species.

The absence of PST in the Limfjord samples, where these toxins have been documented earlier in connection with $A$. ostenfeldii (Hansen et al., 1992) was somewhat unexpected. The PST profiles reported by these authors for a strain isolated from Limfjord (CCMP1773) were however quite unusual, consisting of $>90 \%$ B2. They were never confirmed by later analyses (Krock, unpublished). Generally, brackish water populations of $A$. ostenfeldii can produce PST together with spirolides and/or gymnodimines (Kremp et al., 2009; van de Waal et al., 2015; Harju et al., 2016), but this ability seems to be ribotype specific. Both new Limfjord strains and other strains representing the A. ostenfeldii Limfjord ribotype (Kremp et al., 2014) were never found to produce PST, and so far all investigated members lack sxt genes (Suikkanen et al., 2013a).

\subsection{Alexandrium pseudogonyaulax, a toxic bloom former expanding in $N$ - European waters?}

The predominance of Alexandrium pseudogonyaulax and goniodomins in the Alexandrium community of the three investigated water bodies is an unexpected result of this survey. In previous reports, this species has not raised much attention compared to other Alexandrium species in the area (e.g. Larsen and Moestrup, 1989), although it has been occasionally listed as present in past cyst and plankton records from the North Sea (Balech, 1995; Nehring, 1997). Being quite a rare background species in the area, its North European populations were never characterized properly.

Here we provide, for the first time, documentation of North European strains. While the plate morphology largely agrees with the characterization provided by Balech (1995), the Limfjord and North Sea strains are more variable in size and shape. The cells are generally smaller and not as wide and compressed as typical for A. pseudogonyaulax described from other locations, though variation among the isolates exists. A large range of sizes and varying shapes of cells in cultured strains might in part be due to the presence of gametes (smaller and round, see Montresor, 1995) and other stages of the sexual cycle. In some of the cultured strains nuclear cyclosis, a clear sign of sexual reproduction was observed. Vegetative cell division of the Limfjord cultures was as previously described, in division cysts (Montresor, 1995), however para-tabulate resting cysts (Montresor, 1993) were never seen in sediments and/or cultures: Cysts found in the sediment here, lacked para-tabulation similar to in other regions (Bravo et al., 2006). This may be due to the brackish salinities in the area: processes and other surface structures of dinoflagellate resting cysts are often reduced in low salinity environments (Mertens et al., 2011). Unfortunately, the $28 \mathrm{~S}$ sequence data generated here for the isolated strains were not able to resolve relationships to other geographic populations, e.g. from Asia, New Zealand (Gu et al., 2013) or North Africa (Zmerli Triki et al., 2014). This could suggest that the species has spread from a geographically distant source population relatively recently, but firm conclusions cannot be made due to the limited availability of sequence data.

The wide distribution and predominance of A. pseudogonyaulax in the Alexandrium community shown here for the investigated North SeaLimfjord-Baltic Sea transect indicate an ongoing expansion of the species in northern Europe. This is corroborated by the clear change observed in 2007-2008 in the composition of the Alexandrium spp. community in the Limfjord long term monitoring data. For a yet unclear reason, A. pseudogonyaulax suddenly replaced other Alexandrium spp. in the early summer phytoplankton community with cell concentrations exceeding Alexandrium spp. by one order of magnitude. An explanation for this shift is not directly evident. It could be assumed that specific hydrographic changes observed over the past two decades in the Limfjord (Carstensen et al., 2013) including an increase in temperature, might play a role here. However, as explained above, physical habitat conditions seem to be equally tolerated by $A$. ostenfeldii and A. pseudogonyaulax. Both species are reported to phagocytize other organisms (Gribble et al., 2005; Jeong et al., 2010) and should respond similarly to changed nutrient conditions. Nevertheless, A. pseudogonyaulax has a particularly effective "food" acquisition strategy that is unique among mixotrophic protists: it produces toxic mucus, which traps and concentrates protist prey cells (Blossom et al., 2012, 2017). This feeding mechanism increases the growth of the species and provides a clear competitive advantage. 
It could be assumed that through this mechanism A. pseudogonyaulax benefits specifically from high phytoplankton productivity fueled by climate enhanced river discharge from the catchment area (Blanda et al., 2016). Besides providing suitable temperature conditions, climate change may thus indirectly favour A. pseudogonyaulax in brackish waters affected by high riverine inflow. Possibly such a mechanism is also responsible for the recently observed high biomass occurrences of the species in summer phytoplankton of the western and southern Baltic Sea (Wasmund et al., 2015, 2017).

\section{Conclusions}

This field survey revealed that salinity alone does not determine abundances and composition of Alexandrium species and their toxins, but emphasizes the importance of habitat conditions such as proximity to seed banks, shelter, and high nutrient concentrations. The results show that A. pseudogonyaulax is now a prominent member of the Alexandrium spp. community. Analyses of long term monitoring data from Limfjord confirmed a recent shift to A. pseudogonyaulax dominance in Alexandrium spp. Our results and interpretations support the initially suspected expansion of A. pseudogonyaulax in Northern European waters. Cyst and toxin records of the species in Kiel Bight suggest a spreading potential into the brackish Baltic Sea, where it might expand in the future and form blooms when climate warming continues. At the same time our data indicate that A. pseudogonyaulax has the potential to cause problems in Scandinavian waters since it produces GDA. This toxin can accumulate in marine shellfish and fish and lead to invertebrate mortalities with potentially severe consequences for aquaculture and the shellfish industries in the area.

\section{Author contributions}

The original idea was developed by AK, BK, PJH and UT. AK coordinated the activities, analyzed cyst samples and wrote the manuscript draft, to wich all coauthors contributed. PJH coordinated the field campaign in Limfjorden and participated in material collection. UT collected material and performed taxonomic analyses, HS developed and performed the qPCR assay for quantification of Alexandrium spp, S.S. participated the cruise and performed statistical analyses, DV and FB measured and analyzed hydrography, HHJ analyzed long term data. BK organized and lead the research cruise and took charge of the toxin analyses.

\section{Funding}

This work was partially financed by the Academy of Finland (Decision No. 310449), the Helmholtz-Gemeinschaft Deutscher Forschungszentren through the research program PACES of the AlfredWegener-Institut, Helmholtz Zentrum für Polar- und Meeresforschung, the European Commission under the 7th Framework Programme through the Action-IMCONet (FP7 IRSES, Action No. 319718) and the Innovation Fund Denmark, through the HABFISH project (Project No. 0603-00449B).

\section{Acknowledgements}

Rohan Henkel, Kai Schwalfenberg and Anna Friedrichs of ICBM, Annegret Müller of AWI and Zlatina Peteva from the Medical University of Varna are acknowledged for their help with logistics and onboard work during the cruise. Kaisu Jussila and Salla Ahonen helped with processing the sediment samples.[CG]

\section{Appendix A. Supplementary data}

Supplementary material related to this article can be found, in the online version, at doi:https://doi.org/10.1016/j.hal.2019.101622.

\section{References}

Altschul, S.F., Madden, T.L., Schaffer, A.A., Zhang, J., Zhang, Z., Miller, W., Lipman, D.J., 1997. Gapped BLAST and PSI-BLAST: a new generation of protein database search programs. Nucleic Acids Res. 25 (17), 3389-3402.

Anderson, D.M., 1998. Physiology and bloom dynamics of toxic Alexandrium species, with emphasis on life cycle transitions. In: Anderson, D.M., Cembella, A.D., Hallegraeff, G.M. (Eds.), Physiological Ecology of Harmful Algal Blooms. Springer, Berlin, pp. 29-48.

Anderson, D.M., Alpermann, T.J., Cembella, A.D., Collos, Y., Masseret, E., Montresor, M., 2012. The globally distributed genus Alexandrium: multifaceted roles in marine ecosystems and impacts on human health. Harmful Algae 14, 10-35.

Arar, E.J., Collins, G.B., 1997. Method 445.0: in vitro determination of chlorophyll A and pheophytin A in marine and freshwater algae by fluorescence. U.S. Environ. Prot. Agency.

Aure, J., Danielsen, D., Svendsen, E., 1998. The origin of Skagerrak coastal water off Arendal in relation to variations in nutrient concentrations. ICES J. Mar. Sci. 55, 610-619.

Ayres, P.A., 1975. Mussel poisoning in Britain with special reference to paralytic shellfish poisoning. A review of cases reported 1814-. Environmental Health 83 (7), 261-265.

Balech, E., 1995. The Genus Alexandrium Halim. Sherkin Island Marine Station, Cork, Ireland $151 \mathrm{pp}$.

Biecheler, B., 1952. Recherches sur les Péridiniens. Bull. Biol. France Belg. 36 (Suppl), $1-149$.

Bill, B.D., Moore, S.K., Hay, L.R., Anderson, D.M., Trainer, V.L., 2016. Effects of temperature and salinity on the growth of Alexandrium (Dinophyceae) isolates from the Salish Sea. J. Phycol. 52 (2), 230-238.

Blanda, E., Hansen, B.W., Højgård, J., Jepsen, P.M., Pedersen, M.F., Rayner, T.A. Thoisen, C.V., Jakobsen, H.H., 2016. Inorganic nitrogen addition in a semi-intensive turbot larval aquaculture system: effects on phytoplankton and zooplankton composition. Aquac. Res. 47, 3913-3933.

Blossom, H.E., Bædkel, T.D., Tillmann, U., Hansen, P.J., 2017. A search for mixotrophy and mucus trap production in Alexandrium spp. and the dynamics of mucus trap formation in Alexandrium pseudogonyaulax. Harmful Algae 64, 51-62.

Blossom, H.E., Daugbjerg, N., Hansen, P.J., 2012. Toxic mucus traps: a novel mechanism that mediates prey uptake in the mixotrophic dinoflagellate Alexandrium pseudogonyaulax. Harmful Algae 17, 40-53.

Bolch, C.J.S., 1997. The use of sodium polytungstate for the separation and concentration of living dinoflagellate cysts from marine sediments. Phycologia 36 (6), 472-478.

Bravo, I., Garcés, E., Diogène, J., Fraga, S., Sampedro, N., Figueroa, R.I., 2006. Resting cysts of the toxigenic dinoflagellate genus Alexandrium in recent sediments from the Western Mediterranean coast, including the first description of cysts of A.kutnerae and A.peruvianum. Eur. J. Phycol. 41 (3), 293-302.

Bresnan, E., Turrell, E.A., Fraser, S., 2008. Monitoring PSP and Alexandrium hotspots in Scottish waters. In Proceedings of the 12th International Conference on Harmful Algae. Intergovernmental Oceanographic Commission of UNESCO 51-54.

Brown, L., Bresnan, E., Graham, J., Lacaze, J.P., Turrell, E., Collins, C., 2010. Distribution, diversity and toxin composition of the genus Alexandrium (Dinophyceae) in Scottish waters. Eur. J. Phycol. 45 (4), 375-393.

Bustin, S., Benes, V., Garson, J., Hellemans, J., Huggett, J., Kubista, M., Mueller, R., Nolan, T., Pfaffl, M.W., Shipley, G.J., Vandesompele, J., Wittwer, C.T., 2009. The MIQE guidelines: minimum information for publication of quantitative real-time PCR experiments. Clin. Chem. 55 (4), 611-622.

Carstensen, J., Krause-Jensen, D., Markager, S., Timmermann, K., Windolf, J., 2013. Water clarity and eelgrass responses to nitrogen reductions in the eutrophic Skive Fjord, Denmark. Hydrobiologia 704 (1), 293-309.

Cembella, A.D., Lewis, N.I., Quilliam, M.A., 2000. The marine dinoflagellate Alexandrium ostenfeldii (Dinophyceae) as the causative organism of spirolide shellfish toxins. Phycologia 39 (1), 67-74.

Collins, C., Graham, J., Brown, L., Bresnan, E., Lacaze, J.P., Turrell, E.A., 2009. Identification and toxicity of Alexandrium tamarense (Dinophyceae) in Scottish waters 1. J. Phycol. 45 (3), 692-703.

Dittami, S.M., Hostyeva, V., Egge, E.S., Kegel, J.U., Eikrem, W., Edvardsen, B., 2013. Seasonal dynamics of harmful algae in outer Oslofjorden monitored by microarray, qPCR, and microscopy. Environ. Sci. Pollut. Res. 20 (10), 6719-6732.

Eckford-Soper, L.K., Bresnan, E., Lacaze, J.P., Green, D.H., Davidson, K., 2016. The competitive dynamics of toxic Alexandrium fundyenseand non-toxicAlexandrium tamarense: The role of temperature. Harmful Algae 53, 135-144.

Etheridge, S.M., Roesler, C.S., 2005. Effects of temperature, irradiance, and salinity on photosynthesis, growth rates, total toxicity, and toxin composition for Alexandrium fundyense isolates from the Gulf of Maine and Bay of Fundy. Deep. Sea Res. Part II 52 (19-21), 2491-2500.

Fraga, S., Sampedro, N., Larsen, J., Moestrup, Ø, Calado, A.J., 2015. Arguments against the proposal 2302 by John \& al. to reject the name Gonyaulax catenella (Alexandrium catenella). Taxon 64 (3), 634-635.

Garneau, M.E., Countway, S.A., Jones, A.C., Seubert, E.L., Caron, D.A., 2011 Examination of the seasonal dynamics of the toxic dinoflagellate Alexandrium catenella at Redondo Beach, California, by quantitative PCR. Appl. Environ. Microbiol. 77, 7669-7680.

Godhe, A., Sjöqvist, C., Sildever, S., Sefbom, J., Harðardóttir, S., Bertos-Fortis, M., Bunse, C., Gross, S., Johansson, E., Jonsson, P.R., Khandan, S., Legrand, C., Lips, I., Lundholm, N., Rengefors, K., Sassenhagen, I., Suikkanen, S., Sundqvist, L., Kremp, A., 2016. Physical barriers and environmental gradients cause spatial and temporal genetic differentiation of an extensive algal bloom. J. Biogeogr. 43 (6), 1130-1142.

Gribble, K.E., Keafer, B.A., Quilliam, M.A., Cembella, A.D., Kulis, D.M., Manahan, A., 
Anderson, D.M., 2005. Distribution and toxicity of Alexandrium ostenfeldii (Dinophyceae) in the Gulf of Maine, USA. Deep. Sea Res. Part II 52 (19-21), 2745-2763.

Gu, H., Zeng, N., Liu, T., Yang, W., Müller, A., Krock, B., 2013. Morphology, toxicity, and phylogeny of Alexandrium (Dinophyceae) species along the coast of China. Harmful Algae 27, 68-81.

Gu, H., 2011. Morphology, phylogenetic position, and ecophysiology of Alexandrium ostenfeldii (Dinophyceae) from the Bohai Sea, China. J. Syst. Evol. 49 (6), 606-616.

Gyllencreutz, R., Backman, J., Jakobsson, M., Kissel, C., Arnold, E., 2006. Postglacial palaeoceanography in the Skagerrak. Holocene 16, 973-983.

Hakanen, P., Suikkanen, S., Franzen, J., Franzen, H., Kankaanpää, H., Kremp, A., 2012. Bloom and toxin dynamics of Alexandrium ostenfeldii in a shallow embayment at the SW coast of Finland, northern Baltic Sea. Harmful Algae 15, 91-99.

Hansen, P.J., Cembella, A.D., Moestrup, Ø., 1992. The marine dinoflagellate Alexandrium ostenfeldii: paralytic shellfish toxin concentration, composition, and toxicity to a tintinnid ciliate 1. J. Phycol. 28 (5), 597-603.

Hansen, J.W., 2018. Marine Områder 2014 NOVANA. Aarhus, Aarhus Universitet. (In Danish Language) Videnskabelig Rapport Fra DCE -Nationalt Center for Miljø Og Energi.Marine Områder 2014 NOVANA. Aarhus, Aarhus Universitet. (In Danish Language) Videnskabelig Rapport Fra DCE -Nationalt Center for Miljø Og Energi.

Harju, K., Koskela, H., Kremp, A., Suikkanen, S., de la Iglesia, P., Miles, C.O., Krock, B., Vanninen, P., 2016. Identification of gymnodimine D and presence of gymnodimine variants in the dinoflagellate Alexandrium ostenfeldii from the Baltic Sea. Toxicon 112, $68-76$.

Higman, W.A., Stone, D.M., Lewis, J.M., 2001. Sequence comparisons of toxic and nontoxic Alexandrium tamarense (Dinophyceae) isolate from UK waters. Phycologia 40 (3), 256-262.

Hinder, S.L., Hays, G.C., Edwards, M., Roberts, E.C., Walne, A.W., Gravenor, M.B., 2012. Changes in marine dinoflagellate and diatom abundance under climate change. Nat. Clim. Change 2 (4), 271.

Honsell, G., Boni, L., Cabrini, M., Pompei, M., 1992. Toxic or potentially toxic dinoflagellates from the Northern Adriatic Sea. Mar. Coast. Eutrophication 107-114.

Hsia, M.H., Morton, S.L., Smith, L.L., Beauchesne, K.R., Huncik, K.M., Moeller, P.D. 2006. Production of goniodomin A by the planktonic, chain-forming dinoflagellate Alexandrium monilatum (Howell) Balech isolated from the Gulf Coast of the United States. Harmful Algae 5 (3), 290-299.

Jakobsen, H.H., Carstensen, J., Harrison, P.J., Zingone, A., 2015. Estimating time series phytoplankton biomass: species identifications and comparing volume to carbon scaling ratios. Est. Coast. Shelf Sci. 162, 143-150.

Jeong, H.J., Du Yoo, Y., Kim, J.S., Seong, K.A., Kang, N.S., Kim, T.H., 2010. Growth, feeding and ecological roles of the mixotrophic and heterotrophic dinoflagellates in marine planktonic food webs. Ocean Sci. J. 45 (2), 65-91.

John, U., Cembella, A., Hummert, C., Elbrächter, M., Groben, R., Medlin, L., 2003. Discrimination of the toxigenic dinoflagellates Alexandrium tamarense and A. ostenfeldii in co-occurring natural populations from Scottish coastal waters. Eur. J. Phycol. 38 (1), 25-40.

John, U., Litaker, R.W., Montresor, M., Murray, S., Brosnahan, M.L., Anderson, D.M., 2014. Formal revision of the Alexandrium tamarense species complex (Dinophyceae) taxonomy: the introduction of five species with emphasis on molecular-based (rDNA) classification. Protist 165 (6), 779-804.

Kaas, H., Markager, S., 1998. Technical Guidelines for Marine Monitoring. from. http:// bios.au.dk/videnudveksling/til-myndigheder-og-saerligt-interesserede/ fagdatacentre/fdcmarintny/tekniske-anvisninger-nova-1998/.

Keller, M.D., Seluin, R.C., Claus, W., Guillard, R.R.L., 1987. Media for the culture of oceanic ultraphytoplankton. J. Phycol. 23, 633-638.

Klein, G., Martin, J.L., Kaczmarska, I., 2010. Biological synopsis of phytoplankton new to the Bay of Fundy. Can. Manuscr. Rep. Fish. Aquat. Sci 2919: v + 28 p.

Krause-Jensen, D., Markager, S., Dalsgaard, T., 2012. Benthic and pelagic primary production in different nutrient regimes. Estuaries Coast. 35, 527-545.

Kremp, A., Tahvanainen, P., Litaker, W., Krock, B., Suikkanen, S., Leaw, C.P., Tomas, C., 2014. Phylogenetic relationships, morphological variation, and toxin patterns in the Alexandrium ostenfeldii (Dinophyceae) complex: implications for species boundaries and identities. J. Phycol. 50 (1), 81-100.

Kremp, A., Lindholm, T., Dreßler, N., Erler, K., Gerdts, G., Eirtovaara, S., Leskinen, E., 2009. Bloom forming Alexandrium ostenfeldii (Dinophyceae) in shallow waters of the Åland archipelago, Northern Baltic Sea. Harmful Algae 8 (2), 318-328.

Krock, B., Tillmann, U., Wen, Y., Hansen, P.J., Larsen, T.O., Andersen, A.J.C., 2018. Development of a LC-MS/MS method for the quantification of goniodomins A and B and its application to Alexandrium pseudogonyaulax strains and plankton field samples of Danish coastal waters. Toxicon 155, 51-60.

Krock, B., Zielinski, O., Friedrichs, A., Henkel, R., Schwalfenberg, K., Voß, D., 2017. Physical Oceanography During UTHÖRN Cruise UT201606 (HAB-DK/Limfjord). Institute for Chemistry and Biology of the Marine Environment, Carl-von-Ossietzky University of Oldenburg, Germany, PANGAEA. https://doi.org/10.1594/PANGAEA 874076.

Krock, B., Tillmann, U., John, U., Cembella, A.D., 2008. LC-MS-MS aboard ship: tandem mass spectrometry in the search for phycotoxins and novel toxigenic plankton from the North Sea. Anal. Bioanal. Chem. 392 (5), 797-803.

Krock, B., Seguel, C.B., Cembella, A.D., 2007. Toxin profile of Alexandrium catenella from the Chilean coast as determined by liquid chromatography with fluorescence detection and liquid chromatography coupled with tandem mass spectrometry. Harmful Algae 6 (5), 734-744.

Larsen, J., Moestrup, O., 1989. Guide to Toxic and Potentially Toxic Marine Algae. Fish Inspection Service. Ministry of Fisheries.

MacKenzie, A.L., White, D., Oshima, Y., Kapa, J., 1996. The resting cyst and toxicity of Alexandrium ostenfeldii (Dinophyceae) in New Zealand. Phycologia 35 (2), 148-155.

Martens, H., et al. Salinity effects on growth and toxin production in an Alexandrium ostenfeldii (Dinophyceae) isolate from The Netherlands. Journal of Plankton Research 38.5 (2016): 1302-1316.

Martens, H., Tillmann, U., Harju, K., Dell'Aversano, C., Tartaglione, L., Krock, B., 2017. Toxin variability estimations of 68 Alexandrium ostenfeldii (Dinophyceae) strains from the Netherlands reveal a novel abundant gymnodimine. Microorganisms 5 (2), 29.

Mertens, K.N., Dale, B., Ellegaard, M., Jansson, I.M., Godhe, A., Kremp, A., Louwye, S., 2011. Process length variation in cysts of the dinoflagellate Protoceratium reticulatum, from surface sediments of the Baltic-Kattegat-Skagerrak estuarine system: a regional salinity proxy. Boreas 40 (2), 242-255.

Moestrup, O., Hansen, P.J., 1988. On the occurrence of the potentially toxic dinoflagellates Alexandrium tamarense ( = Gonyaulax excavata) and A. ostenfeldii in Danish and Faroese waters. Ophelia 28 (3), 195-213.

Møller, J.S., 1996. Water masses, stratification and circulation. Coast. Estuar. Stud. 52, 51-66. https://doi.org/10.1029/CE052p0051.

Montresor, M., 1993. The paratabulate resting cyst of Alexandrium pseudogonyaulax (Dinophyceae). Toxic Phytoplankton Blooms in the Sea. pp. 159-164.

Montresor, M., 1995. The life history of Alexandrium pseudogonyaulax (Gonyaulacales, Dinophyceae). Phycologia 34 (6), 444-448.

Murakami, M., Makabe, K., Yamaguchi, K., Konosu, S., Walchli, M.R., 1988. Goniodomin A, a novel polyether macrolide from the dinoflagellate Goniodoma pseudogonyaulax. Tetrahedron Lett. 29 (10), 1149-1152.

Nehring, S., 1997. Dinoflagellate resting cysts from recent German coastal sediments. Bot. Mar. 40, 307-324.

$\emptyset$ stergaard-Jensen, M., Moestrup, Ø., 1997. Autecology of the toxic dinoflagellate Alexandrium ostenfeldii: life history and growth at different temperatures and salinities. Eur. J. Phycol. 32 (1), 9-18.

Okonechnikov, K., Golosova, O., Fursov, M., U. team, 2012. Unipro UGENE: a unified bioinformatics toolkit. Bioinformatics 28, 1166-1167.

Savela, H., Harju, K., Spoof, L., Lindehoff, E., Meriluoto, J., Vehniainen, M., Kremp, A., 2016. Quantity of the dinoflagellate sxtA4 gene and cell density correlates with paralytic shellfish toxin production in Alexandrium ostenfeldii blooms. Harmful Algae 52, $1-10$.

Scholin, C., Herzog, A.M., Sogin, M., Anderson, D.M., 1994. Identification of group- and strain-specific genetic markers for globally distributed Alexandrium (Dinophyceae). II. Sequence analysis of a fragment of the LSU rDNA gene. J. Phycol. 30, 999-1011.

Sjöqvist, C.O., Kremp, A., 2016. Genetic diversity affects ecological performance and stress response of marine diatom populations. ISME J. 10 (11), 2755.

Suikkanen, S., Kremp, A., Hautala, H., Krock, B., 2013a. Paralytic Shellfish Toxins or Spirolides? The role of environmental and genetic factors in toxin production of Alexandrium ostenfeldii/ peruvianum. Harmful Algae 26, 52-59.

Suikkanen, S., Pulina, S., Engström-Öst, J., Lehtiniemi, M., Lehtinen, S., Brutemark, A., 2013b. Climate change and eutrophication induced shifts in northern summer plankton communities. PLoS One 8 (6), e66475.

Tangen, K., 1983. Shellfish poisoning and the occurrence of potentially toxic dinoflagellates in Norwegian waters. Sarsia 68 (1), 1-7.

Tillmann, U., Kremp, A., Tahvanainen, P., Krock, B., 2014. Characterization of spirolide producing Alexandrium ostenfeldii (Dinophyceae) from the western Arctic. Harmful Algae 39, 259-270.

Toebe, K., Alpermann, T.J., Tillmann, U., Krock, B., Cembella, A., John, U., 2013 Molecular discrimination of toxic and non-toxic Alexandrium species (Dinophyta) in natural phytoplankton assemblages from the Scottish coast of the North Sea. Eur. J. Phycol. 48 (1), 12-26.

Touzet, N., Franco, J.M., Raine, R., 2008. Morphogenetic diversity and biotoxin compo sition of Alexandrium (Dinophyceae) in Irish coastal waters. Harmful Algae 7 (6), 782-797.

Van de Waal, D.B., Tillmann, U., Martens, H., Krock, B., van Scheppingen, Y., John, U., 2015. Characterization of multiple isolates from an Alexandrium ostenfeldii bloom in The Netherlands. Harmful Algae 49, 94-104.

Wasmund, N., Dutz, J., Pollehne, F., Siegel, H., Zettler, M.L., 2015. Biological assessment of the Baltic Sea 2014. Meereswiss. Ber., Warnemünde 98.

Zmerli Triki, H.Z., Daly-Yahia, O.K., Malouche, D., Komiha, Y., Deidun, A., Brahim, M., Laabir, M., 2014. Distribution of resting cysts of the potentially toxic dinoflagellate Alexandrium pseudogonyaulax in recently-deposited sediment within Bizerte Lagoon (Mediterranean coast, Tunisia). Mar. Pol. Bull. 84, 172-181.

Zmerli Triki, H., Laabir, M., Kéfi Daly-Yahia, O., 2015. Life history, excystment features, and growth characteristics of the Mediterranean harmful dinoflagellate Alexandrium pseudogonyaulax. Journal of Phycology 51 (5), 980-989.

Zmerli Triki, H., Laabir, M., Moeller, P., Chomérat, N., Kéfi Daly-Yahia, O., 2016. First report of goniodomin A production by the dinoflagellate Alexandrium pseudogonyaulax developing in southern Mediterranean (Bizerte Lagoon, Tunisia). Toxicon 111, 91-99. 